\title{
DIALOGUE AND DECLARATIONS OF INCOMPATIBILITY UNDER SECTION 4 OF THE HUMAN RIGHTS ACT 1998
}

\author{
Christopher Crawford ${ }^{*}$
}

\begin{abstract}
It has been argued that the Human Rights Act 1998 ('HRA') establishes a 'dialogue' between the courts, parliament and the executive. This 'dialogue' is supposed to be an exchange of ideas about rights pursuant to which policy goals are revised, but not blocked, following judicial decisions and takes place predominantly when courts issue declarations of incompatibility under s 4 of the HRA. There have been 18 cases in which declarations have become final. This article considers those 18 cases and their legislative aftermaths. It reveals, firstly, that parliament has some capability of dealing with rights issues without the courts' prompting, secondly, that a declaration can certainly lead to constructive modification of public policy but may also lead to less effective policy and, thirdly, that parliament has no real freedom to disagree with the conclusions of the courts on questions of rights when a declaration has been made.
\end{abstract}

\section{INTRODUCTION}

When the Human Rights Act 1998 ('HRA') was enacted, many commentators claimed that it would establish a 'dialogue' between the courts, parliament and the executive. ${ }^{1}$

\footnotetext{
* Barrister-at-Law, Doctoral candidate at Queensland University of Technology.

${ }^{1}$ Sandra Fredman 'Bringing Rights Home' (1998) 114 (October) LQR 538, 538-539; Sandra Fredman 'Allies or Subversives? The Judiciary and Democracy' (1998) 32 Is LR 407, 422-424; Sandra Fredman 'Judging Democracy: The Role of the Judiciary under the HRA 1998' (2000) 53(1) CLP 99, 119; Ben Emmerson 'Constitutional Law: Human Rights' [1998] EHRLR 663, 663; Francesca Klug 'The Human Rights Act 1998, Pepper v Hart and All That' [1999] PL 246, 248; Murray Hunt 'The Human Rights Act and Legal Culture: The Judiciary and the Legal Profession' (1999) 26(1) J Law \& Soc 86, 89-90; Joanna Miles 'Standing under the Human Rights Act 1988: theories of rights enforcement and the nature of public law adjudication' (2000) 59(1) CLJ 133, 164; Joanna Harrington 'Rights Brought Home: The United Kingdom Adopts a 'Charter of Rights' (2001) 11 Const Forum Const 105, 111.
} 


\section{DIALOGUE AND DECLARATIONS OF INCOMPATIBILITY UNDER SECTION 4 OF THE HUMAN RIGHTS ACT 1998}

The concept of 'dialogue' under the HRA has been explained by Alison Young in her book, Parliamentary Sovereignty and the Human Rights Act. ${ }^{2}$

In her book, Young defined 'democratic dialogue models' as protections of human rights that do not grant the courts the final ability to make authoritatively determinative accounts as to the compatibility of legislation with human rights; rather, "mechanisms are incorporated into the legal protection of rights that enable the legislature to respond to judicial determinations as to the compatibility of legislation with human rights".

Young noted that the term 'democratic dialogue' derived from a wellknown journal article by Peter Hogg and Allison Thornton (nee Bushell). ${ }^{4}$ In their article, Hogg and Thornton argued that where judicial decisions were open to legislative reversal, modification or avoidance, it was appropriate to regard the relationship between the courts and the legislature as a dialogue. ${ }^{5}$ It was upon this basis that Young found it 'easy to conclude' ${ }^{6}$ that the HRA provided for a democratic dialogue model of rights protection: judicial decisions taken under both ss 3 and 4 of the HRA were open to reversal, modification or avoidance by the legislature.

Section 3(1) of the HRA is an interpretative provision. It provides that, so far as it is possible to do so, primary and subordinate legislation in the United Kingdom must be read and given effect in a way that is compatible with the rights set out in Schedule 1 to the HRA. The rights set out in Schedule 1 come from the European Convention on Human Rights ('Convention'). ${ }^{7}$ Section $3(2)$ (b) provides that, if primary legislation is incompatible with Convention rights, that does not affect its validity, continuing operation or enforcement.

Section 4(2) of the HRA provides that if a court ${ }^{8}$ is satisfied that primary legislation is incompatible with Convention rights, it may make a declaration

2 Alison Young, Parliamentary Sovereignty and the Human Rights Act (Hart Publishing 2009). See also Richard Clayton, 'Judicial Deference and Democratic Dialogue': The Legitimacy of Judicial Intervention under the Human Rights Act 1998' [2004] PL 33; cf Tom Hickman 'Constitutional Dialogue, Constitutional Theories and the Human Rights Act 1998' [2008] PL 306.

${ }^{3}$ Young (n 2) 25-26.

4 Peter Hogg and Allison Bushell, 'The Charter Dialogue Between Courts and Legislatures (Or Perhaps the Charter of Rights Isn't Such a Bad Thing After All)' (1997) 35 OHLJ 75.

${ }^{5}$ Ibid $79-80$.

${ }^{6}$ Young (n 2) 113.

${ }^{7}$ Convention for the Protection of Human Rights and Fundamental Freedoms, opened for signature 4 November 1950, 213 UNTS 221 (entered into force 3 September 1953).

${ }^{8}$ When the HRA was originally enacted, the term 'court' was defined in s 4(5) as (a) the House of Lords, (b) the Judicial Committee of the Privy Council, (c) the Courts- 
of that incompatibility. Section 4(6)(a) states that a declaration does not affect the validity, continuing operation or enforcement of the statutory provision in respect of which it is given. Section 10(2) provides that, if a court makes a declaration then, if a Minister considers that there are compelling reasons, he may by order make such amendments to the legislation as he considers necessary to remove the incompatibility. Schedule 2 to the HRA sets out the process by which remedial orders are made.

Young asserted that ss 3 and 4 established two different forms of dialogue. ${ }^{9}$ She contended that dialogue took place predominantly when courts issued s 4 declarations. ${ }^{10}$ It is this form of dialogue with which this journal article is concerned.

Young argued that a declaration provided a signal to parliament that legislation contained provisions that were contrary to Convention rights. She asserted that a declaration could prompt the legislature to debate if and how to respond to the courts; it could respond either by amending legislation to ensure its compatibility with Convention rights, or by providing a justification for its maintenance on the statute books. ${ }^{11}$ Importantly, Young claimed that the legislature had the freedom to disagree with the conclusions of the courts as to the modifications required to ensure Convention compatibility. ${ }^{12}$

The dialogue portrayed by Young is akin to the 'institutional interaction' described by Leighton McDonald: an exchange of ideas about human rights between the parliament and the courts pursuant to which policy goals are revised, but not blocked, following judicial decisions. ${ }^{13}$

The attraction of the concept of dialogue is obvious: if parliament chooses to amend legislation following a declaration then the amendment should be constructive from a rights standpoint; if it disagrees with the judicial decision

Martial Appeal Court, (d) in Scotland, the High Court of Justiciary sitting otherwise than as a trial court or the Court of Session and (e) in England and Wales or Northern Ireland, the High Court or the Court of Appeal. Following the creation of the UK Supreme Court, s 4(5)(a) was amended by omitting the words 'House of Lords' and inserting the words 'Supreme Court'.

9 Young (n 2) 26. Young noted, in passing, that the derogation power and 'the qualified rights found in articles 8-11 of the Convention' would also facilitate dialogue but she did not explore the issue any further than that. She clearly considered ss 3 and 4 to be the main drivers of dialogue: see Young (n 2) 113-114.

${ }^{10}$ Ibid 10.

${ }^{11}$ Ibid.

${ }^{12}$ Ibid 116.

${ }^{13}$ Leighton McDonald, 'New Directions in the Australian Bill of Rights Debate' [2004] PL 22, 28. 


\section{DIALOGUE AND DECLARATIONS OF INCOMPATIBILITY UNDER SECTION 4 OF THE HUMAN RIGHTS ACT 1998}

then it is free to do so. In other words, dialogue should lead 'to a better outcome for rights as well as democracy'. ${ }^{14}$

Perhaps unsurprisingly, some say that dialogue under the HRA is nothing more than a 'fantasy' that merely raises the question of who gets the last word. ${ }^{15}$ James Allan has argued that it is the judiciary that has the final say on rights issues. ${ }^{16}$ Allan contended that, in practice, is almost always impossible for a legislature to disagree with the conclusions of the courts, ${ }^{17}$ contrary to Young's claim. Allan asserted that, as the judges' views always prevailed over those of the legislature, that in no way resembled a dialogue. ${ }^{18}$

Young's arguments are interesting in light of the fact that the government that introduced the HRA did not actually assert that it would precipitate 'democratic dialogue'. ${ }^{19}$ They are of further interest in light of the fact that two senior Law Lords, Lord Bingham of Cornhill and Lord Phillips of Worth Matravers, expressly denied that the HRA involved a dialogue between the courts, parliament and the executive. ${ }^{20}$ They are of still further interest when one considers that, despite the protestations of Lords Bingham and Phillips, many commentators have continued to maintain that the HRA has established a dialogue about rights between the three arms of government. ${ }^{21}$ The purpose

${ }^{14}$ Irene Khan, 'Human rights in an age of terror' in Nicolas Kang-Riou, Confronting the Human Rights Act 1998: Contemporary Themes and Perspectives (Taylor and Francis 2012) 105.

${ }^{15}$ Keith Ewing, 'Doughty defenders of the Human Rights Act' in Nicolas Kang-Riou, Confronting the Human Rights Act 1998: Contemporary Themes and Perspectives (Taylor and Francis 2012) 122. For other criticisms of dialogue under the HRA, see Keith Ewing and Joo Cheong Tham, 'The Continuing Futility of the Human Rights Act' [2008] PL 668, 691; Philip Sales and Richard Ekins, 'Rights-consistent interpretation and the Human Rights Act 1998' (2011) 127 (April) LQR 217, 236; Ian Leigh and Roger Masterman, Making Rights Real: The Human Rights Act in its First Decade (Hart Publishing 2008) 118.

16 James Allan, 'The Victorian Charter of Human Rights and Responsibilities: Exegesis and Criticism’ (2006) 30(3) MULR 880, 914.

${ }^{17}$ Ibid 915.

18 Ibid 913.

19 There was no mention of dialogue in either the consultation paper or the White Paper that preceded the introduction of the HRA: see Jack Straw and Paul Boateng 'Bringing Rights Home: Labour's Plans to incorporate the European Convention on Human Rights into UK Law' [1997] EHRLR 71; Rights Unit, UK Parliament, Rights Brought Home: The Human Rights Bill (Cm 3782, 1997).

${ }^{20}$ Joint Committee on Human Rights, Minutes of Evidence taken on Monday 26 March 2001: Examination of Witnesses (2000-01, HL 66-ii, HC 332-ii), [78].

${ }^{21}$ Francesca Klug, 'The Human Rights Act - a 'Third Way' or 'Third Wave' Bill of Rights' [2001] EHRLR 361, 370; Richard Edwards 'Judicial Deference under the Human Rights Act' (2002) 65 MLR 859, 867; Lizzie Barmes “Adjudication and 
of this article is to examine the extent to which dialogue does take place when courts issue declarations of incompatibility under s 4 of the HRA.

As at 1 January 2013, 27 declarations of incompatibility had been made by the courts since the HRA came into force on 2 October 2000 . Of these, 18 have become final (in whole or in part) and are not subject to further appeal whilst 9 have been overturned on appeal. ${ }^{22}$ The 18 cases in which declarations have been finalised and their legislative aftermaths will be considered below in chronological order from earliest to most recent.

\section{2. $R$ (H) V LONDON NORTH AND EAST REGION MENTAL HEALTH REVIEW TRIBUNAL [2001] EWCA CIV 415, [2002] QB 1}

This case concerned a patient who made an application to a mental health review tribunal to be discharged from detention in hospital, which was refused. The patient then sought judicial review by way of a declaration of incompatibility under s 4 of the HRA, which was also refused. The patient appealed. The Court of Appeal allowed the appeal and declared that ss 72(1) and 73(1) of the Mental Health Act 1983 were incompatible with the right to

public opinion" (2002) 118 (October) LQR 600, 621; Keir Starmer 'Two years of the Human Rights Act' [2003] EHRLR 14, 18; Clayton (n 2) 42-45; Bharat Malkani 'Human rights treaties in the English legal system' [2011] PL 554, 575; Po-Jen Yap 'Defending Dialogue' [2012] PL 527, 527 n 2.

${ }^{22}$ Ministry of Justice, United Kingdom, Responding to human rights judgments: Report to the Joint Committee on Human Rights on the Government's response to human rights judgments 2011-12 (Cm 8432, 2012), 40. In this report, it is recorded that, as at 31 July 2012, 27 declarations had been made by the UK courts. It is also noted that, of these 27 declarations, 19 had become final (in whole or in part) and were not subject to further appeal and 8 had been overturned on appeal. The report is incorrect in counting $R$ (Hooper) $v$ Secretary of State for Work and Pensions [2003] EWCA Civ 875 as a declaration that had become final. The correct interpretation of Hooper is that a declaration was made at first instance in respect of repealed legislation: see $R$ (Hooper) $v$ Secretary of State for Work and Pensions [2002] EWHC 191 (Admin). On appeal to the Court of Appeal, the declaration was discharged: see $R$ (Hooper) v Secretary of State for Work and Pensions [2003] EWCA Civ 875 [1]. On appeal to the Judicial Committee of the House of Lords, it was held that, as the relevant legislative provisions had been repealed, there was no point in their Lordships making a declaration: see $R$ (Hooper) $v$ Secretary of State for Work and Pensions [2005] UKHL 29, [2005] 1 WLR 1681, 1696-7. Accordingly, the making of the declaration in Hooper was, in reality, overturned on appeal. Therefore, as at 31 July 2012, 27 declarations had been made by the UK courts, of which 18 had become final (in whole or in part) and were not subject to further appeal and 9 had been overturned on appeal. 


\section{DIALOGUE AND DECLARATIONS OF INCOMPATIBILITY UNDER SECTION 4 OF THE HUMAN RIGHTS ACT 1998}

liberty under article 5(1)(4) of the Convention in that, for the tribunal to be obliged to order a patient's discharge, the burden was placed upon the patient to prove that the criteria justifying his detention in hospital for treatment no longer existed; and that article 5(1)(4) required the tribunal to be positively satisfied that all the criteria justifying the patient's detention in hospital for treatment continued to exist before refusing a patient's discharge.

In order to remove the incompatibility, the Mental Health Act 1983 (Remedial) Order 2001 amended ss 72(1) and 73(1) to provide that a mental health review tribunal had to direct the discharge of a patient if it was not satisfied that the criteria justifying his/her detention in hospital for treatment continued to exist.

The House of Lords considered the Mental Health Act 1983 (Remedial) Order 2001 on 11 April 2002. In moving the approval of the Order, the Labour Government Whip, Lord Filkin, made the following comments about $H$ :

"It was the government's view that there was no discernible error of law in the Court of Appeal's judgment and in addition, the judgment was not out of line with the thrust of government policy intentions for new mental health legislation as set out in the White Paper Reforming the Mental Health Act." ${ }^{, 23}$

The Order was supported by the Conservative and Liberal Democrat parties (the Conservative peer, Baroness Noakes, described it as 'clearly necessary') and was duly approved. ${ }^{24}$

The Court of Appeal's decision in $H$ was uncontroversial. All sides of British politics accepted that ss 72(1) and 73(1) of the Mental Health Act 1983 were incompatible with the right to liberty. The declaration may very well have resulted in a constructive modification to legislation.

\section{RE AN APPLICATION FOR JUDICIAL REVIEW BY MCR [2002] NIQB 58}

This case concerned a Northern Irishman who was charged with attempted buggery pursuant to s 62 of the Offences against the Person Act 1861. The Sexual Offences Act 1967 effectively decriminalised homosexual acts in private in England and Wales but s 62 remained in force in Northern Ireland. The accused applied for a declaration that s 62 was incompatible with his

\footnotetext{
${ }^{23}$ HL Deb 1 April 2002, vol 633, col 601. See also HC Deb 28 October 2002, vol 391, col 627 (Jean Corston).

${ }^{24}$ HL Deb 11 April 2002, vol 633, col 603-607.
} 
right to a private life under article 8 of the Convention. The application was not opposed by the Crown. In a short judgment, the High Court of Justice in Northern Ireland referred to two decisions of the European Court of Human Rights ('ECtHR') where it was noted that there was no pressing social need for the criminalisation of homosexual acts between consenting adult males performed in private. The Court made the declaration sought pursuant to $\mathrm{s} 4$ of the HRA.

By the time $M c R$ was decided, the process of modernising British law on sexual offences had been underway for some time. A review of sex offences was set up by the UK government in 1999, the independent review group producing a consultation paper in July 2000. In addition the government carried out a review of Part 1 of the Sex Offenders Act 1997 and proposals were published for public consultation by Home Office in July 2001. These two reviews fed into a White Paper, Protecting the Public: strengthening protection against sex offenders and reforming the law on sexual offences, published in November 2002. ${ }^{25}$ Relevantly, the White Paper stated as follows:

"Certain existing offences criminalise consensual sexual activity in private between men, which would not be illegal between heterosexuals or between women. In order to provide common sense and making policing the law fair and practicable, these offences will be replaced with generic offences. This will ensure that the criminal law protects everyone equally from non-consensual sexual activity, but does not criminalise sexual activity that takes place between consenting adults in private." 26

The White Paper was followed by the enactment of the Sexual Offences Act 2003, which repealed s 62 of the Offences against the Person Act 1861.

By 2002, the British government accepted that it should not intervene in the personal, private relationships of consenting adults. ${ }^{27}$ This was obviously the reason why the Crown did not oppose the High Court in Northern Ireland making the declaration of incompatibility. There is no reason to suspect that the decision in $M c R$ was anything other than uncontentious.

\footnotetext{
${ }^{25}$ Arabella Thorp, 'The Sexual Offences Bill (No 128) 2002-03 (UK)' (Research Paper 03/62 House of Commons Library, United Kingdom Parliament, 2003) 3.

${ }^{26}$ Secretary of State for the Home Department, Protecting the Public: Strengthening protect against sex offenders and reforming the law on sexual offences (Cm 5668, 2002) 10.

${ }^{27}$ Ibid 5 (Foreword by the then Home Secretary, David Blunkett).
} 


\section{INTERNATIONAL TRANSPORT ROTH GMBH V SECRETARY OF STATE FOR THE HOME DEPARTMENT [2002] EWCA CIV 158, [2003] QB 728}

This case concerned a penalty scheme created pursuant to s 32 of the Immigration and Asylum Act 1999, which made carriers liable to a fixed penalty of $£ 2,000$ for every clandestine entrant to the United Kingdom found concealed in a vehicle. The owner, hirer and driver were liable unless they could establish that they were acting under duress or that they had no knowledge of the clandestine entrant and that there was an effective system for preventing the carriage of clandestine entrants which was operated properly on the occasion in question. Once the Home Secretary had issued a penalty notice a senior immigration officer could detain the vehicle if he considered there was a serious risk that the penalty would not be paid and no satisfactory alternative security had been given. In several joined proceedings, groups of claimants brought proceedings against the Home Secretary, challenging the lawfulness of the penalty scheme.

The Court of Appeal held that the scale and inflexibility of the penalty without the possibility of mitigation or the right for the penalty to be determined by an independent tribunal were factors which made the scheme unfair and in breach of the claimants' right to a fair hearing under article 6 of the Convention. The Court of Appeal also held that the scheme imposed an excessive burden on the carriers which was disproportionate to the objective to be achieved and was a breach of the claimants' right to peaceful enjoyment of their possessions under article 1 of the First Protocol to the Convention. Accordingly, the Court of Appeal held that a declaration that the scheme was incompatible with article 6 of the Convention and article 1 of the First Protocol to the Convention was appropriate.

Just before the Court of Appeal handed down its decision in Roth, the government released a White Paper on immigration and asylum policy. ${ }^{28}$ The majority of the White Paper proposals were incorporated into the subsequent Nationality, Immigration and Asylum Act 2002. ${ }^{29}$ The new Act also incorporated a response to Roth. Section 125 and Schedule 8 of the Nationality, Immigration and Asylum Act 2002 amended the penalty scheme under s 32 of the Immigration and Asylum Act 1999 by introducing a new

28 Secretary of State for the Home Department, Secure Borders, Safe Haven: Integration with Diversity in Modern Britain (Cm 5387, 2002). The White Paper was published on 7 February 2012 (HC Deb 7 February 2002, vol 379, col 1027). Roth was handed down on 22 February 2002.

29 Dallal Stevens, 'The Nationality, Immigration and Asylum Act 2002: Secure Boarders, Safe Haven?' (2004) 67(4) MLR 616, 617. 
variable penalty of up to $£ 4,000$ for those carrying clandestine entrants by road or rail, a right of appeal to the County Court against the imposition and/or size of the penalty and the power for the Court to release a confiscated vehicle where it thought that penalty was not appropriate. ${ }^{30}$

Members of the government, including the Home Secretary, expressly stated that they thought the new penalty scheme was 'fair'." Although members of a government are hardly likely to say that new legislation is unfair, there is no evidence that they were uncomfortable with the new penalty scheme or with the Roth decision. On the contrary, the Lord Chancellor indicated that he thought that the Roth decision was principled and fair. ${ }^{32}$ Some Conservative and Liberal Democrat Lords clearly wanted to lessen the severity of the penalty scheme even more. ${ }^{33}$ In those circumstances, it seems likely that a majority of parliament accepted, in a real way, the revised penalty regime brought about by Roth.

\section{R (ANDERSON) V SECRETARY OF STATE FOR THE HOME DEPARTMENT [2002] UKHL 46, [2003] 1 AC 837}

The claimant had been convicted of two murders for which he received mandatory life sentences. By his stated practice, adopted pursuant to his power to control the release of such prisoners under s 29 of the Crime (Sentences) Act 1997, the Home Secretary received advice from the trial judge, the Lord Chief Justice and departmental officials prior to deciding the minimum period to be served by the claimant. In fixing the claimant's tariff, ${ }^{34}$ the Home Secretary set a longer period than that recommended by the judiciary. The claimant challenged the decision by way of judicial review. On 25 November 2002, the Judicial Committee of the House of Lords declared that s 29 of the Crime (Sentences) Act 1997 was incompatible with the right under article 6 of the Convention to have a sentence imposed by an independent and impartial tribunal.

\footnotetext{
${ }^{30}$ David Blunkett, 'UK Government: Criminal Refugees to be removed from country' M2 Presswire (online), 25 April 2002; M2 Presswire, 'UK Government: New penalties for carrying illegal immigrants start tomorrow' M2 Presswire (online), 9 December 2002.

${ }^{31}$ Ibid. See also HC Deb 21 May 2002, vol 386, col 61WH (John Denham).

${ }^{32}$ Lord Irvine 'The Impact of the Human Rights Act: Parliament, the Courts and the Executive' [2003] PL 308, 318.

${ }^{33}$ HL Deb 17 July 2002, vol 637, col $1354-1357$.

34 The minimum period of imprisonment that a murderer had to serve before release was considered was known as the 'tariff'.
} 


\section{DIALOGUE AND DECLARATIONS OF INCOMPATIBILITY UNDER SECTION 4 OF THE HUMAN RIGHTS ACT 1998}

Anderson was a case 'waiting to happen, ${ }^{35}$ because judicial erosion of the Home Secretary's tariff-setting power had already begun by the time it was decided. ${ }^{36}$ In May 2002, the ECtHR held in Stafford v United Kingdom ${ }^{37}$ that the Home Secretary's veto of a parole board's recommendation that a posttariff lifer should be released was contrary to the prisoner's right under article 5 of the Convention to have the lawfulness of his detention decided speedily by a court. The Home Secretary, David Blunkett, said the following in relation to the Stafford judgment:

"I am disappointed with this judgment which has the effect of removing the Home Secretary's statutory power to decide the release - on Parole Board recommendations - of adult murderers whose tariff has expired...I am concerned that this judgment may serve as encouragement for those who would like to remove the Home Secretary's powers to set tariffs for adult murderers. If this judgment were to be used to support a legal process to achieve this, I would seek to use domestic legislation to enshrine the power of Parliament to provide adequate punishment for the guilty - including life meaning life. Policy on the protection of the public and punishment of the guilty must always be the domain of the elected Parliament." 38

It was pretty obvious that the Home Secretary thought that the Stafford decision was wrong. ${ }^{39}$ It was also clear that, as a result of Stafford, $\mathrm{Mr}$ Anderson would probably win his appeal when it was heard later that year. ${ }^{40}$ However, it was less obvious as to what the government intended to do if the result of Mr Anderson's appeal was as expected. In July, the government was maintaining that it was "necessary for the maintenance of public confidence in the criminal justice system that decisions relating to the length of time a murderer spends in custody and release are taken by the Home Secretary" ${ }^{41}$; however by October Mr Blunkett's aides were saying that the Home Secretary

\footnotetext{
${ }^{35}$ Christopher Gale and Annabelle James, 'Comment: Mandatory Life Sentences and Executive Interference' (2002) 66 JCL 417, 421.

${ }^{36}$ This process is described in detail in Stephen Shute 'Punishing Murderers: Release Procedures and the "Tariff”, 1953-2004' [2004] Crim L Rev 873.

37 (2002) 35 EHRR 32.

${ }^{38}$ M2 Communications Ltd, 'UK Government: Stafford Judgement' M2 Presswire (online), 28 May 2002.

${ }^{39}$ Stephen Pollard, David Blunkett (Hodder and Stoughton 2005) 4.

${ }^{40}$ Clare Dyer, 'Blunkett Loses Key Power to Keep Killers in Jail' The Guardian (London) 29 May 2002, 1.7.

${ }^{41}$ David Barrett, 'We should decide killer's fate, says top judge' Daily Post (London) 9 July 2002, 19.
} 
would simply bring in a new law to make sure "life means life" if $\mathrm{Mr}$ Anderson's appeal was successful. ${ }^{42}$

On 28 October 2002, the Conservative Opposition moved a resolution in the Commons that the House 'notes with concern the impact of the Convention on the sentencing powers of the Home Secretary... and calls upon the Government...to construct a lasting settlement that can bring the [HRA] into conformity with the democratic will of the people... ${ }^{43}$ The resolution was defeated but it seems fairly clear that parliament had begun to seriously consider what it would do if confronted by a declaration on a topic of real public interest. $^{44}$

Anderson was then handed down. Mr Blunkett promised to introduce new legislation which would establish a clear set of principles within which judges would fix minimum tariffs for murderers in the future, thus indicating that the Home Secretary would no longer have that power. ${ }^{45}$ The government then introduced amendments to the Criminal Justice Bill which transferred the power to fix tariffs in mandatory lifer cases from the Home Secretary to the sentencing judge. The legislation also established statutory guidelines which had to be taken into account by judges when they set the minimum terms that murderers had to serve before they became eligible for parole. ${ }^{46}$

The guidelines were designed to place very substantial constraints on sentencing judges. That this is so can be seen from the Explanatory Notes to the Criminal Justice Act 2003, which state that while 'there may be a few very exceptional cases in which starting points [for minimum terms] will be increased or decreased very substantially, it is expected that the vast majority

${ }^{42}$ David Leppard and Zoe Thomas, 'Legal Ruling may Free 200 Killers Early' Sunday Times (London) 6 October 2002, 10.

${ }^{43}$ HC Deb 28 October 2002, vol 391, col 605 (Dominic Grieve).

${ }^{44}$ There were a couple of references to dialogue during the Commons debate on 28 October 2002 (HC Deb 28 October 2002, vol 391, col 605-651) but no agreement as to its form. Vera Baird (Labour, Redcar) stated (at col 639): 'There is no doubt that a healthy tripartite dialogue has been engendered between the courts, Parliament and the Executive by the Human Rights Act. They have all worked together'. However, Dominic Grieve (Conservative, Beaconsfield) stated (at col 612-613): 'We have had an extraordinary paradigm shift in the way in which we run our affairs. Some might argue that that is for the better. However, it involves a dialogue between the Executive and the judiciary, from which Parliament is effectively excluded. I have serious doubts about that process. As the dialogue continues, there is a danger that the process of justice, Parliament and the Executive will be brought into disrepute with the public'.

${ }^{45}$ HC Deb 25 November 2002, vol 395, col 100-101W.

${ }^{46}$ Shute (n 36) 890. 


\section{DIALOGUE AND DECLARATIONS OF INCOMPATIBILITY UNDER SECTION 4 OF THE HUMAN RIGHTS ACT 1998}

of cases will tend to attract minimum terms that reflect [those prescribed by the Act]'. ${ }^{47}$

After noting that the Home Secretary's role of examining tariff cases was 'horrendous', $\mathrm{Mr}$ Blunkett explained the motivation behind the new legislation in the following terms:

"We want to reassert the role of Parliament that historically existed when considering cases of murder, and to ensure that there is clarity and a response to public concern...

"Today I am responding to the [Anderson] judgment. Although I accept that it takes the tariff out of the hands of the Home Secretary as I said, no Home Secretary would be sorry to see that go - we are trying to achieve the same result." 48

Although it may have been traumatic to consider horrific murders, it seems unlikely that Mr Blunkett wanted to give up his tariff setting power. He knew that he could hand that power over to the judiciary but he fought $\mathrm{Mr}$ Anderson all the way to the House of Lords to try and keep it. Even after Anderson went against him, he introduced legislation that had, as he saw it, the express purpose of retaining the status quo; that is, accountability to the public for sentences served by murderers.

If Mr Blunkett had tried to retain his tariff setting power after Anderson, he may very well have received the support of the Conservative Party ${ }^{49}$ and a large section of the general public. As noted above, he wanted to retain parliament's accountability to the public for terms of imprisonment served by murderers. Anderson did not, of course, change or strike down any law: the House of Lords merely declared s 29 of the Crime (Sentences) Act 1997 to be incompatible with the Convention. Why then did $\mathrm{Mr}$ Blunkett and the government not simply ignore Anderson?

There was probably a combination of reasons. Firstly, the government may have considered that the new legislation would be effective; that is, it would force the judiciary to hand down the minimum sentences that the government wanted. Secondly, it may not have wanted to provoke a political fight with those who believed that the Home Secretary had no place setting tariffs and/or that the judiciary should not be questioned on matters of human

\footnotetext{
${ }^{47}$ Explanatory Notes to the Criminal Justice Act 2003 (UK) 642 [835].

${ }^{48}$ HC Deb 20 May 2003, vol 405, col 865-870.

49 After Stafford was handed down, the shadow Home Secretary, Oliver Letwin, said, 'We believe that the Home Secretary should retain the ability to overrule the parole board in cases involving murderers': Dyer (n 40).
} 
rights. ${ }^{50}$ Thirdly, and most likely, the government recognised that $\mathrm{Mr}$ Anderson would simply take his case to the ECtHR where he would win. $\mathrm{Mr}$ Blunkett was advised by the Home Office that he had no chance of success in Strasbourg because of the ECtHR's decision in Stafford. ${ }^{51}$

Sir Philip Sales and Richard Ekins disagree with Young's conclusion that the HRA establishes a dialogue between the judiciary and the legislature. ${ }^{52}$ They say that the root of the problem with Young's approach is that it fails to identify what is, in fact, a fundamental feature of the HRA, namely, that it provides domestic remedies for rights drawn from international law. Sales and Ekins note that the ECtHR does not perceive itself to be participating in any form of democratic dialogue with each European legislature, 'nor could it sensibly do so'. ${ }^{53}$ The judgments of the ECtHR are legally binding on all three branches of the United Kingdom government so it is difficult, politically and legally, for the United Kingdom parliament to legislate inconsistently with judgments of the ECtHR. ${ }^{54}$ Sales and Ekins conclude that the 'Strasbourg dimension' is a 'fundamental aspect of the [HRA]'.

After Anderson was handed down, Merris Amos wrote the following:

"The judgment of the House of Lords was...a prime example of the courts, parliament and the executive engaging in a dialogue at the end

\footnotetext{
${ }^{50}$ For example, just prior to Anderson being handed down, the Liberal Democrat home affairs spokesman, Simon Hughes, was quoted as saying, 'It would be wrong, even if understandable, for the home secretary to resist any judgment that went against him': see Vikram Dodd and Clare Dyer, 'His Life in Whose Hands? Sarah Payne killer ordered to serve 50 years: Law lords to strip Home Secretary of right to set terms for murderers' The Guardian (London) 25 November 2002, 1.3.

${ }^{51}$ Dodd and Dyer, ibid.

52 Philip Sales and Richard Ekins (n 15) 236.

${ }^{53}$ Ibid 227-228.

${ }^{54}$ Jason Varuhas 'Courts in the service of Democracy: Why Courts Should Have a Constitutional (But Not Supreme) Role in Westminster Legal Systems' [2009] NZ Law Review 481, 515. Judgments of the ECtHR are of a declaratory nature: they state whether and to what extent there has been a violation of a human rights guarantee under the Convention. Pursuant to article 46 of the Convention, the United Kingdom is obliged to abide by any judgment in a case to which it is a party. It is an underlying norm of international law that a state will bring to an end any continuing or future violation of human rights of the kind mentioned in the judgment. There are examples of reluctance on the part of some states to follow the reasoning of the ECtHR but in the long run all the states have accepted its jurisprudence: see Georg Ress, 'The Effect of Decisions and Judgments of the European Court of Human Rights in the Domestic Legal Order' (2005) 40 Tex ILJ 359.

55 Sales and Ekins (n 15) 229.
} 


\section{DIALOGUE AND DECLARATIONS OF INCOMPATIBILITY UNDER SECTION 4 OF THE HUMAN RIGHTS ACT 1998}

of which fundamental human rights emerged victorious as was intended by the architects of the [HRA]. ${ }^{, 56}$

If dialogue under the $H R A$ is supposed to be an exchange of ideas about human rights between parliament and the courts pursuant to which policy goals are revised, but not blocked, following judicial decisions, there is real reason to doubt the accuracy of Amos' statement. It is clear that parliament was well aware of the case for the Home Secretary's role to be transferred to the judiciary; after all, as Amos accepts, numerous challenges to this role had been brought domestically and in the ECtHR.$^{57} \mathrm{Mr}$ Anderson's appeal could not have raised any new "ideas" about human rights; hence, there could hardly have been an exchange of ideas about them.

The government fought to retain the Home Secretary's power; Amos admits that Mr Blunkett 'was anxious to retain his role'. ${ }^{58}$ Once the House of Lords handed down its decision, the government relinquished that power. Was this an example of a policy goal being blocked or merely modified?

The answer to this question depends upon what the policy goal actually was. If the goal was to ensure adequate punishment for murderers then an assessment of whether that goal has been achieved after Anderson is beyond the reach of this article. However, it seems fairly clear that Mr Blunkett formed the view that, in order to ensure that murderers received adequate punishment, it was necessary for the executive to have direct control of their minimum terms of imprisonment. If that was the government's goal then it was undoubtedly not achieved.

Was that objective 'blocked'? The 'Strasbourg dimension' was patently an important factor in the government's decision-making process. Although the government may have been anxious to retain its power, it knew that the ECtHR would demand its surrender. The government's hand was clearly forced by the prospect of an inevitably adverse ECtHR judgment. ${ }^{59}$

Anderson did not produce an exchange of ideas about human rights. Depending on one's view of what the government's policy goal actually was, the process may very well have been closer to a monologue, judges doing the talking and legislatures the listening, ${ }^{60}$ than the dialogue alleged by Amos.

\footnotetext{
${ }^{56}$ Merris Amos ' $\mathrm{R} v$ Secretary for the Home Department, ex p Anderson - Ending the Home Secretary’s Sentencing Role' (2004) 67(1) MLR 108,116-117.

57 Ibid 108 .

58 Ibid 117.

${ }^{59}$ Ibid: Amos describes the outcome in Anderson as 'somewhat inevitable' (117), 'a foregone conclusion' (117) and 'not unexpected' (122).

${ }^{60}$ Frederick Morton and Rainer Knopff, The Charter Revolution and the Court Party (Broadview Press 2000) 166.
} 


\section{6. $R$ (D) V SECRETARY OF STATE FOR THE HOME DEPARTMENT [2002] EWHC 2805 (ADMIN), [2003] 1 WLR 1315}

This case concerned a claimant who had been sentenced to a discretionary term of life imprisonment. He was subsequently transferred to a mental hospital and made the subject of restrictions. The claimant served the minimum period of his detention and applied for discharge. The mental health review tribunal did not have the power to order a patient's discharge. Under $\mathrm{s}$ 74(1) of the Mental Health Act 1983, the mental health review tribunal was obliged to notify the Secretary of State whether, in its opinion, the patient was entitled to be discharged. Under s 74(1)(b) of the Mental Health Act 1983, if the tribunal formed the opinion that a patient was entitled to be conditionally discharged, the tribunal could recommend that, in the event of the patient not being discharged, the patient should continue to be detained in hospital. It was the Secretary of State's policy to refer to the Parole Board the cases of all restricted patients who remained in hospital following a tribunal recommendation under s 74(1)(b). The Parole Board had the power to direct the release of a patient; however there was no statutory right of access to a board hearing. Mr Justice Stanley Burnton made a declaration under s 4 of the HRA that the absence of any power in s 74 of the Mental Health Act 1983 to order the release of a prisoner: (a) who was sentenced to a discretionary life sentence; and (b) who was transferred to hospital and made subject to restrictions; and (c) who was subsequently the subject of a recommendation under s 74(1)(b) of the Mental Health Act 1983; and (d) who remained in hospital, was incompatible with his right to have the lawfulness of his detention decided speedily by a court pursuant to article 5(4) of the Convention.

Section 295 of the Criminal Justice Act 2003 amended s 74 of the Mental Health Act 1983 by inserting a new subsection (5A), which gave transferees such as the claimant in $D$ a right of access to the Parole Board. As it was the policy of the Home Secretary, prior to $D$, to refer all such transferees to the Parole Board anyway, the amendment was 'a change in form more than substance'. ${ }^{61}$ The uncontroversial nature of the amendment was reflected in the fact that it was introduced and agreed to in the House of Lords without debate. $^{62}$

\footnotetext{
${ }^{61}$ Peter Bartlett and Ralph Sandland, Mental Health Law: Policy and Practice $\left(3^{\text {rd }}\right.$ ed, OUP 2007) 417.

${ }^{62}$ HL Deb 14 October 2003, vol 653, col 918-920.
} 


\section{BLOOD AND TARBUCK V SECRETARY OF STATE FOR HEALTH (HIGH COURT OF ENGLAND AND WALES, SULLIVAN J, 28 FEBRUARY 2003, UNREPORTED)}

The facts of this case were reported in The Telegraph and Daily Mail newspapers on 28 February $2003 .{ }^{63}$ According to those newspaper reports, Mrs Blood and Mrs Tarbuck used the sperm of their respective deceased husbands to conceive children. Under s 28(6)(b) of the Human Fertilisation and Embryology Act 1990, a man could not be named as the father of a child if his sperm was used to fertilise an egg after his death. The result was that the Blood and Tarbuck children's birth certificates did not state their fathers' names. The legal proceedings appear to have been brought by Mrs Blood and Mrs Tarbuck on their own account and on behalf of their children. The parties to the litigation agreed that the court should make a declaration pursuant to $\mathrm{s} 4$ of the HRA that s. 28(6)(b) was incompatible with human rights. Mr Justice Sullivan (as he then was) made a declaration in the terms sought.

The Human Fertilisation and Embryology (Deceased Fathers) Act 2003 introduced new subsections into s 28 of the Human Fertilisation and Embryology Act 1990, which set out the circumstances in which certain deceased men could be registered as the father on a child's birth certificate.

The Human Fertilisation and Embryology (Deceased Fathers) Act 2003 was uncontentious, which is reflected in the fact that the declaration in Blood and Tarbuck was made with the consent of the Health Secretary. In 2001, the Labour government supported a private Members Bill that would have allowed a child conceived by in vitro fertilisation after the father's death to record his/her father's name on his/her birth certificate but it did not complete all its stages before the general election was called that year. ${ }^{64}$ When the issue was raised again in parliament in 2003, the Human Fertilisation and Embryology (Deceased Fathers) Act was passed with the support of all sides of politics. ${ }^{65}$

\section{BELLINGER V BELLINGER [2003] UKHL 21, [2003] 2 AC 467}

The petitioner was a transsexual female who had been correctly classified and registered at birth as male but had undergone gender reassignment surgery. In 1981 she went through a ceremony of marriage with a man who

\footnotetext{
${ }^{63}$ The case is also noted in Ministry of Justice (n 22) 47.

${ }^{64}$ HC Deb 23 March 2001, vol. 365, col 642-650; HC Deb 24 January 2002, vol 378, col 1090W.

${ }^{65}$ HC Deb 28 March 2003, vol. 402 col 602-612; HL Deb 4 July 2003, vol 650, col 1148-1163.
} 
supported her petition for a declaration that the marriage was valid at its inception and subsisting. The judge at first instance refused to grant the declaration on the ground that 'male' and 'female' in s 11(c) of the Matrimonial Causes Act 1973 were to be determined by reference to biological criteria and that the petitioner was a male and not a woman for the purposes of marriage.

On 10 April 2003, the Judicial Committee of the House of Lords dismissed her appeal but made a declaration pursuant to $\mathrm{s} 4$ of the HRA that $\mathrm{s}$ 11(c) was incompatible with the petitioner's right to respect for her private life under article 8(1) of the Convention and with her right to marry under article 12 of the Convention.

By the time that Bellinger was decided, steps were well underway to allow transsexual people to be officially recognised in the gender with which they identified. In 1999, the Home Secretary set up the Interdepartmental Working Group on Transsexual People. The Working Group published a report in April 2000, which put forward a number of options but suggested that the government put the matters out to public consultation. The Working Group was reconvened in 2002 to examine the implications of granting full legal status to transsexual people in their acquired gender. ${ }^{66}$

On 11 July 2002, the ECtHR delivered judgments in favour of two transsexual people in Goodwin v United Kingdom ${ }^{67}$ and I v United Kingdom ${ }^{68}$, which effectively obliged the British government to recognise sex changes as legally valid. On 13 December 2002, the government announced that it would publish draft legislation that would give transsexual people legal recognition in their acquired gender. ${ }^{69}$

On 27 November 2003, the Gender Recognition Bill had its first reading in the House of Lords. ${ }^{70}$ It eventually passed both houses of parliament: 155 votes for to 57 against in the Lords and 335 votes for to 26 against in the Commons. ${ }^{71}$ The Gender Recognition Act 2004 enabled transsexual people to apply for legal recognition of their acquired gender. Successful applicants would be issued with a gender recognition certificate and would have the right

\footnotetext{
66 Catherine Fairbairn, 'The Gender Recognition Bill (No. 56) 2003-04 (UK)' (Research Paper 04/15 House of Commons Library, United Kingdom Parliament, 2004), 10-11.

${ }^{67}$ (2002) 35 EHRR 447.

${ }^{68}$ (2003) 36 EHRR 53.

${ }^{69}$ Fairbairn (n 66) 11-15.

${ }^{70}$ HL Deb 27 November 2003 vol 655, col 24.

${ }^{71}$ HL Deb 10 February 2004 vol 656, col 1090-1092; HC Deb 23 February 2004, vol 418, col 105-108.
} 


\section{DIALOGUE AND DECLARATIONS OF INCOMPATIBILITY UNDER SECTION 4 OF THE HUMAN RIGHTS ACT 1998}

to marry in their acquired gender and be given birth certificates that recognised the acquired gender.

The Gender Recognition Act 2004 was the outcome, not of the decision in Bellinger, but of the Working Group's consultation with the transsexual community in the United Kingdom and of the ECtHR's judgments in Goodwin and $I^{72}$ Indeed, in Bellinger, counsel for the intervening Lord Chancellor submitted that a declaration would serve no useful purpose as the government had already announced its intention to bring forward primary legislation on the subject. ${ }^{73}$ Bellinger did not result in any real exchange of ideas about human rights between parliament and the courts because the issue was already being fully considered by the government by the time the decision was handed down.

\section{9. $R$ (M) V SECRETARY OF STATE FOR HEALTH [2003] EWHC 1094 (ADMIN)}

The claimant was a 34 year old woman with a borderline personality disorder who was liable to detention under the Mental Health Act 1983. She had made allegations of sexual abuse against her adoptive father, which were denied by him. The claimant's adoptive father was her 'nearest relative' as that term was defined in s 26 of the Mental Health Act 1983. The Mental Health Act 1983 gave various powers and entitlements to her adoptive father as her 'nearest relative'. Section 29 of the Mental Health Act 1983 enabled the replacement of a patient's 'nearest relative' but only in limited circumstances and not on the application of the patient. As there were no legal means available to the claimant to compel her adoptive father's replacement, she applied for a declaration that ss 26 and 29 of the Mental Health Act 1983 were incompatible with her right to respect for her private life under article 8 of the Convention.

In his reasons for judgment, Mr Justice Maurice Kay (as he then was) noted that the Health Secretary admitted that ss 26 and 29 were incompatible with article 8 . His Honour stated that that was not surprising given that the ECtHR had come to that conclusion in JT v United Kingdom ${ }^{74}$. His Honour noted that the judgment of the ECtHR recorded a friendly settlement between JT and the British government pursuant to which the government undertook to amend the Mental Health Act 1983 in order to provide a detainee with the power to make an application to court to have the 'nearest relative' replaced

\footnotetext{
72 Andrew Sharpe 'Gender Recognition in the UK: a Great Leap Forward' (2009) 18(2) Soc \& Legal Stud 241, 242.

${ }^{73}$ Bellinger v Bellinger [2003] 2 AC 467, 471, 481-482.

74 [2000] ECHR 133.
} 
where the patient reasonably objected to a certain person acting in that capacity. Following the friendly settlement in $J T$, no amending legislation had been enacted. The Health Secretary acknowledged the incompatibility but submitted that the government intended to enact amending legislation in the form of a comprehensive Mental Health Bill with a view to a root and branch reform of the 1983 Act. The government had, in fact, published a Draft Bill in the form of the Mental Health Bill 2002. It was for this reason that the Health Secretary submitted that a declaration was unnecessary. As the incompatibility had been identified some time previously but its removal had not taken place, Mr Justice Maurice Kay rejected the government's submission and made the declaration sought.

Sections 23 - 26 of the Mental Health Act 2007 amended ss $26-29$ of the Mental Health Act 1983. In particular, s 23 introduced a new right for a patient to apply for a court order displacing the "nearest relative".

$M$ was similar to Bellinger in that the process of legislative change was well underway by the time the case was decided. If there was an exchange of ideas about human rights, it happened long before $M$ was handed down.

\section{0. $A \quad V$ SECRETARY OF STATE FOR THE HOME DEPARTMENT [2004] UKHL 56, [2005] 2 AC 68 ('BELMARSH')}

Following the terrorist attacks in the United States of America on 11 September 2001, the British government concluded that there was a public emergency threatening the life of the nation within the meaning of article 15 of the Convention. Article 15 relevantly provides as follows:

Derogation in time of emergency

1. In time of war or other public emergency threatening the life of the nation any high contracting party may take measures derogating from its obligations under this Convention to the extent strictly required by the exigencies of the situation, provided that such measures are not inconsistent with its other obligations under international law.

Article 15 is not expressly incorporated by the HRA, but s 14 of the HRA makes provision for prospective derogations by the United Kingdom to be designated in an order made by the Secretary of State. Accordingly, the government made the Human Rights Act 1998 (Designated Derogation) Order 2001, designating the United Kingdom's proposed derogation, under article 15, from the right to personal liberty guaranteed by article 5(1) of the Convention. It then placed the Anti-terrorism, Crime and Security Bill before parliament. 


\section{DIALOGUE AND DECLARATIONS OF INCOMPATIBILITY UNDER SECTION 4 OF THE HUMAN RIGHTS ACT 1998}

Part 4 of the Bill (ss 21 - 36) received a great deal of attention in parliament and was debated publicly at considerable length. ${ }^{75}$ As ultimately enacted, s 21 enabled the Home Secretary to certify that he reasonably believed that a person's presence in the United Kingdom was a risk to national security and that the person was a terrorist. Under s 23, foreign nationals so certified by the Home Secretary could be detained if they could not be deported because of fears for their safety or other practical considerations.

It was pointed out to the Home Secretary, Mr Blunkett, that one of the UK's leading human rights barristers, David Pannick QC, had opined that the derogation from article 5 was unlawful because detention without trial was not strictly required by the exigencies of the situation. Mr Blunkett responded by saying that he was aware of Mr Pannick's comments but had received legal advice that they were incorrect. ${ }^{76}$

Despite the misgivings of some about Part $4,{ }^{77}$ parliament passed the Bill and the Anti-terrorism, Crime and Security Act came into force on 14 December 2001.

Due to the presence of a sunset clause, ${ }^{78}$ parliament was required to revive and renew ss $21-23$ of the Act, which it duly did in $2003 .{ }^{79}$ Under the terms of the sunset clause, any renewal could only last a year so parliament was required to consider ss. $21-23$ again in 2004. By that time, a review of the Act had been conducted by a committee of Privy Counsellors, chaired by Lord Newton of Braintree. The Newton Committee strongly recommended that the powers that allowed foreign nationals to be detained potentially indefinitely be replaced as a matter of urgency. ${ }^{80}$ Parliament noted the report ${ }^{81}$ but decided to renew ss $21-23$ again anyway. ${ }^{82}$

In October 2004, the Judicial Committee of the House of Lords heard an appeal by $\mathrm{A}$ and 8 other foreign nationals who had been detained under s 23 of the Act. As most of the appellants were being held in Belmarsh prison in south-east London, Av Secretary of State for the Home Department became known as the Belmarsh decision.

\footnotetext{
${ }^{75}$ HC Deb 12 December 2001, vol 376, col 911 (David Blunkett).

${ }^{76}$ HC Deb 12 December 2001, vol 376, col 916.

${ }^{77}$ See eg HC Deb 19 November 2001, vol 375, col 95 (Douglas Hogg).

${ }^{78}$ Anti-terrorism, Crime and Security Act 2001 (UK) s 29.

${ }^{79}$ Anti-terrorism, Crime and Security Act 2001 (Continuance in force of sections 21 to 23) Order 2003 (UK); HC Deb 3 March 2003, vol 400, col 584-608.

${ }^{80}$ Privy Councillor Review Committee, Anti-terrorism, Crime and Security Act 2001 Review: Report, (HC December 2003, 100), 11.

${ }^{81}$ HC Deb 25 February 2004, vol 418, col 293-384.

${ }^{82}$ Anti-terrorism, Crime and Security Act 2001 (Continuance in force of sections 21 to 23) Order 2004 (UK). See also HC Deb 3 March 2004, vol 418, col 1027.
} 
On 16 December 2004, the Law Lords handed down their judgment in which they held that since s 23 applied to non-nationals suspected of international terrorism but not to nationals who presented the same threat; permitted non-national suspects to leave the United Kingdom; did not address the threat from nationals; and was capable of applying to individuals who did not pose that threat, it did not rationally address the threat to security and was not strictly required by the exigencies of the situation within the meaning of article 15. Their Lordships held that since the purpose of s 23 was to protect the United Kingdom from the risk of a terrorist attack, which could come from nationals or non-nationals, the fact that only non-national suspects were detained under s 23 meant that a declaration should be made that that section was incompatible with the right to liberty (article 5 of the Convention) and the prohibition against discrimination (article 14 of the Convention) in so far as it was disproportionate and permitted detention of suspected international terrorists in a way that discriminated on the ground of nationality or immigration status.

The next day, the front page of The Guardian newspaper reported that the 'scathing' judgment had 'left anti-terror laws in tatters' ${ }^{83}$ The Foreign Secretary, Jack Straw, was reported as saying that the Law Lords were 'simply wrong' to rule that terror suspects were being held arbitrarily without charge. ${ }^{84}$ The new Home Secretary, Charles Clarke, stated that he would not revoke the s 21 certificates or release the detainees but did say that he would study the judgment carefully to see whether it was possible to modify the Act to address the concerns raised by the Law Lords. ${ }^{85}$

The following day, the front page of The Independent newspaper reported that the government's refusal to withdraw its anti-terror laws had left Britain on the brink of a constitutional crisis. ${ }^{86}$

On 21 December 2004, The Guardian newspaper reported that Mr Clarke was being attacked for failing to announce what the government would do to respond to the judgment. The newspaper reported Conservative MP, Tony Baldry, as saying that the Law Lords 'didn't make an ethical, moral or philosophical judgment... They made a legal judgment'. ${ }^{87}$

${ }^{83}$ Clare Dyer, Michael White and Alan Travis, "Judges' verdict on terror laws provokes constitutional crisis' The Guardian (London) 17 December 2004.

${ }^{84}$ Richard Edwards, 'Law Lords 'wrong' over Detentions, says Straw' Evening Standard (London) 17 December 2004.

${ }^{85}$ Oonagh Blackman 'War on the Law Lords: Clarke defies Decision on Belmarsh Inmates' The Daily Mirror (London) 17 December 2004.

${ }^{86}$ Robert Verkaik and Colin Brown, 'Belmarsh: a new Affront to Justice' The Independent (London) 18 December 2004.

${ }^{87}$ David Hencke and Clare Dyer, 'Clarke criticised over Terror Suspects Ruling' The Guardian (London) 21 December 2004. 


\section{DIALOGUE AND DECLARATIONS OF INCOMPATIBILITY UNDER SECTION 4 OF THE HUMAN RIGHTS ACT 1998}

On 26 January 2005, Mr Clarke told the House of Commons that, although the government believed that the Part 4 powers were justified, he accepted the declaration made by the Law Lords. He indicated that the government had decided to replace the Part 4 powers with a new system of control orders, which would limit the movement and communications of suspected terrorists. ${ }^{88}$

On 3 February 2005, the Lord Chancellor, Lord Falconer of Thoroton, gave a lecture in which he told the audience that he not only accepted the Belmarsh judgment but that the government had got the balance wrong. ${ }^{89}$

On 22 February 2005, Mr Clarke introduced the Prevention of Terrorism Bill into the House of Commons. As he had previously indicated, the Bill introduced a scheme of control orders applicable to all suspected terrorists irrespective of whether they were British or foreign nationals. In his statement to parliament, Mr Clarke made the following comments:

"The Law Lords' judgment on 16 December found that the part 4 powers in the 2001 Act were disproportionate and discriminatory in that they applied only to foreign nationals, and we had apparently managed to contain the threat from British nationals without detention...I accept that judgment, and therefore believe that it is important to address those concerns. We should not simply renew the current legislation, which the Law Lords so overwhelmingly regard as flawed. We should replace it - with strong measures that are fully compatible with the European convention on human rights, and applicable to both British and foreign nationals.",90

On 11 March 2005, parliament enacted the Prevention of Terrorism Act, which repealed ss 21 - 23 of the Anti-terrorism, Crime and Security Act 2001 and replaced detention with control orders.

On 7 July 2005, 52 civilians were killed in a series of terrorist bombings in London. On 26 July 2005, the Prime Minister, Tony Blair, gave a press conference in which he was reminded about Lord Hoffman's comments in the Belmarsh judgment ('The real threat to the life of the nation...comes not from terrorism but from laws such as these' $)^{91}$ and asked whether there was 'any way you can ensure the judges take account of what we think is now public

\footnotetext{
${ }^{88}$ HC Deb 26 January 2005, vol 430, col 305-309.

${ }^{89}$ Adrian Butler and Deborah James, "We got the balance wrong"; Falconer admits anti-terror legislation broke the law' Daily Post (Liverpool) 4 February 2005.

${ }^{90}$ HC Deb 22 February 2005, vol 431, col 152.

${ }^{91}$ A $v$ Secretary of State for the Home Department [2005] 2 AC 68, 132.
} 
and parliamentary opinion?' The Prime Minister responded in the following terms:

"I hope that recent events have created a situation where people can understand that it is important that we do protect ourselves and that in a sense if we can take measures to protect ourselves, it then becomes easier in a sense to protect our own way of life and our democracy and I doubt those words that you were quoting from one of those judgments would be uttered now." $" 92$

The Prime Minister concluded his comments by stating that 'one way of making sure we keep together is to make sure that the laws that I think the country would regard as the minimum necessary are actually passed and are then upheld'. ${ }^{93}$

The Prime Minister's answers were interpreted by some as indicating his disagreement with the Belmarsh decision..$^{94}$ As Mr Blair's autobiography reveals, that interpretation was undoubtedly correct:

"Less happy was the episode over the new anti-terror laws which we were seeking to pass following the House of Lords ruling in December 2004 that our existing power to detain suspects was unlawful under the Convention, which was now incorporated into UK law. Here, there was simply a fundamental disagreement between myself and the judiciary and media; or at least a large part of it, about the threat we faced.

"Although these decisions are supposed to be a strict matter of law, inevitably in the human rights field there is a lot of subjective judgement around the politics. I doubt such a ruling would have been reached in September 2001 or July 2005 - ie in the wake of terrorist attacks in the US and London - but as time passes, the sense of urgency goes with it. And it was true: we were asking for draconian powers, unacceptable in principle except in the most rare circumstances." 95

\footnotetext{
92 'PM's Press Conference - 26 July 2005' (Press Release, 26 July 2005) http://webarchive.nationalarchives.gov.uk/20061004051823/http://number10.gov.uk/p age7999.

93 Ibid.

94 Benedict Brogan, 'Blair: Judges let us Down' Daily Mail (London) 27 July 2005; William Cash, 'Terrorism and the Rule of Law' The Times (London) 2 August 2005.

${ }^{95}$ Tony Blair, A Journey: My Political Life (Alfred A Knopf 2010) 575.
} 


\section{DIALOGUE AND DECLARATIONS OF INCOMPATIBILITY UNDER SECTION 4 OF THE HUMAN RIGHTS ACT 1998}

If the Prime Minister disagreed with Belmarsh, why didn't his government simply refuse to repeal ss $21-23$ of the Anti-terrorism, Crime and Security Act 2001? Mr Blair offered the following explanation in his autobiography:

"Once the House of Lords made the ruling, we had to amend the law." 96

Why was it that the Blair government had to amend the law? The diary of former Labour MP, Chris Mullin, reveals some of the government's thinking on the subject. Mr Mullin attended a meeting at the Prime Minister's office two days before the Belmarsh decision was handed down. His diary records the meeting in the following terms:

"To Number 10 for a meeting about the detentions at Belmarsh..."

"The Attorney General outlines the options. His starting point is that we should obey the forthcoming Lords' judgment, which is expected to go against the government. Alternatively, we could amend the law - 'the difficulty is we don't know what to put in its place."”

"'It will be a big thing, if we don't accept the judgment,' the Attorney General said." 97

What Mr Mullin's diary note exposes is that, not only did the government know that it theoretically had the option of rejecting the Law Lords' judgment, it also knew that it would be a 'big thing' if it took that option. How 'big' of a 'thing' would it have been? Lord Lloyd of Berwick painted a vivid picture in his 2005 Denning Lecture:

"If the Government had rejected the decision in A's case, as it could have done, and renewed Part 4 of the 2001 Act when it expired, there would have been a major constitutional crisis. I shall never forget the sense of relief when...Mr Clarke as Home Secretary announced that the Government would accept the declaration of incompatibility...I would like to think that Mr Clarke's quiet acceptance of the decision in A's case marked the start of a new chapter in the relationship between the judges and the executive. Instead of crying foul, as the

\footnotetext{
96 Ibid.

${ }^{97}$ Ruth Winstone (ed) A View from the Foothills: The Diaries of Chris Mullin (Profile Books 2009) 731-732.
} 
Government might well have done when Mr Blunkett was Home Secretary, the executive has recognised that judges also have a job to do, especially in the realm of human rights. If this is so, then A's case was a decision of huge importance, not only in what it decided, but in the manner of the Government's acceptance of that decision. ${ }^{998}$

In light of the media reports that followed the Belmarsh decision, Lord Lloyd was almost certainly right to surmise that any rejection of the judgment would have resulted in a major constitutional crisis. It should not be forgotten that 2005 was an election year. One can only imagine the hysteria that would have occurred if the government had been seen to 'go against' the judgment of the highest court in the land. The Opposition would have likely had a field day with the issue.

One of the Law Lords who delivered the Belmarsh judgment, Baroness Hale of Richmond, argued in her 2007 Ryan Lecture that, in the United Kingdom, all three organs of government were engaged in a constitutional dialogue..$^{99}$ Lady Hale explained that part of the way that democratic dialogue was supposed to work was that, if legislation was incompatible with fundamental rights, the courts 'decide how far they can go towards putting it right without trespassing on parliamentary sovereignty'. ${ }^{100}$ She explained that parliamentary sovereignty was preserved by the issuing of a declaration because it did not 'affect the validity of anything done under the statue and parliament still has a choice whether or not to do anything about it'. ${ }^{101}$ Lady Hale cited the Belmarsh decision as evidence of the dialogue. ${ }^{102}$

With the greatest of respect to Lady Hale, it seems difficult to classify the outcome of the Belmarsh decision as involving any kind of dialogue. Parliament was well aware of the rights arguments that would be deployed against the Anti-terrorism, Crime and Security Act 2001 in the courts. Despite this, it chose to enact and then renew ss $21-23$ on a number of occasions, in the face of strong criticism. After the Belmarsh decision was handed down, the government clearly did not want to repeal ss $21-23$ but, if it did not do so, it would have provoked a constitutional crisis. Just how little the

\footnotetext{
${ }^{98}$ Lord Lloyd 'The Judges and the Executive - have the Goalposts been Moved?' (2006) 18 Denning LJ 79, 93.

${ }^{99}$ Baroness Hale, 'Human Rights in the Age of Terrorism: the Democratic Dialogue in Action' (2008) 29 Geo J. Int'l L 383, 386.

${ }^{100}$ Ibid 405.

${ }^{101}$ Ibid 388.

${ }^{102}$ Ibid 391-393.
} 


\section{DIALOGUE AND DECLARATIONS OF INCOMPATIBILITY UNDER SECTION 4 OF THE HUMAN RIGHTS ACT 1998}

government thought of Law Lords' decision is demonstrated by the fact that it later took the unusual step of challenging its correctness in the ECtHR. ${ }^{103}$

Despite the protestations of Lord Falconer, the better view is that the government amended the law, not because it thought that it was wrong, but because the political pressure to do anything else was just too great. The reality is that parliament had no choice: it had to amend the law just as $\mathrm{Mr}$ Blair said.

The outcome was not arrived at by an exchange of views: it was dictated by the Law Lords. Prior to the Belmarsh decision being handed down, the Attorney General knew that the government could amend the law but didn't 'know what to put in its place'. The comment suggests that the government needed to know what the courts thought the law should be before it could act. The Law Lords duly did tell the government what they thought the law should be. The leading judgment in Belmarsh was delivered by Lord Bingham who noted that when one of the appellants had been released on bail it was on stringent conditions that limited his freedom of movement and association. ${ }^{104}$ Lord Bingham stated:

"The appellants suggested that conditions of this kind, strictly enforced, would effectively inhibit terrorist activity. It is hard to see why this would not be so." 105

Taking the hint and now knowing what to put in place of detention orders, the government introduced the control order scheme under the Prevention of Terrorism Act 2005.

Some might argue that Belmarsh did not involve the rejection of a key legislative policy goal: the legislative objective was to keep the public safe from foreigners suspected of terrorism and the enactment of the Prevention of Terrorism Act 2005 ensured that that objective was achieved in a way that was properly respectful of human rights. In response, two things can be said. Firstly, it is unlikely that Belmarsh did not result in the blocking of a key policy goal. As Mr Blair says in his autobiography, he conceived of offering foreigners suspected of terrorism a choice: 'leave the country, or stay in custody'. ${ }^{106}$ The Belmarsh decision totally obstructed this objective. Secondly, even if a key objective was not frustrated, the legislature's policy was

\footnotetext{
${ }^{103}$ See $A v$ United Kingdom (2009) 49 EHRR 29; Sangeeta Shah, 'From Westminster to Strasbourg: A and others v United Kingdom' (2009) 9 Co HRLR 473.

${ }^{104}$ A v Secretary of State for the Home Department [2005] 2 AC 68, 106-107.

105 Ibid 107.

${ }^{106}$ Blair (n 95) 575.
} 
distorted, and arguably not in a constructive way. ${ }^{107}$ As Baroness Hale herself noted, seven people who were subject to control orders had, by the time of her lecture, gone missing so 'its effectiveness as a preventive measure is questionable'. ${ }^{108}$

Lord Lloyd was prescient to say that Belmarsh was a decision of huge importance, not only in what it decided, but in the manner of the government's acceptance of that decision. If a government that believed so strongly in legislation on such an important subject matter was not willing to defend it in the face of a declaration, perhaps no government ever would? The outcome of Belmarsh was strong evidence of the proposition that, in the future, it would be, as Lord Lloyd predicted, 'for the judges, and ultimately for Strasbourg, to say what the Convention means'. ${ }^{109}$

\section{1. $R$ (WILKINSON) V INLAND REVENUE COMMISSIONERS [2005] UKHL 30, [2006] 1 ALL ER 529}

The taxpayer was a widower whose wife died on 23 June 1999. At that time, s 262 of the Income and Corporation Taxes Act 1988 provided for a bereavement allowance payable only to widows. By s 34 of the Finance Act 1999, s 262 ceased to have effect in relation to deaths occurring after 6 April 2000. By letter of 11 December 2000, the Inland Revenue Commissioners refused the taxpayer's claim to a payment on the ground that there was no basis in United Kingdom law for allowing widowers to claim the widow's bereavement allowance. The judge refused the taxpayer's claim for judicial review of the commissioners' decision, but granted a declaration that s 262 was incompatible with article 14 of the Convention ('The enjoyment of the rights and freedoms set forth in this Convention shall be secured without discrimination on any ground such as sex...') when read with article 1 of the First Protocol to the Convention ('Every natural or legal person is entitled to the peaceful enjoyment of his possessions'). The taxpayer took his appeal to the House of Lords, arguing that it was possible to read s 262 as including widowers. The House of Lords dismissed his appeal.

Wilkinson did not result in dialogue. The incompatibility was removed by s 34 of the Finance Act 1999, which was enacted well before the taxpayer filed his claim for judicial review.

${ }^{107}$ Christopher Manfredi and James Kelly, 'Six Degrees of Dialogue: A Response to Hogg and Bushell' (1999) 37 OHLJ 513, 522.

${ }_{108}$ Baroness Hale (n 99) 396.

${ }^{109}$ Lord Lloyd (n 98) 93. 


\section{R (MORRIS) V WESTMINSTER CITY COUNCIL (NO 3) [2005] EWCA CIV 1184, [2006] 1 WLR 505: $R$ (GABAJ) $V$ FIRST SECRETARY OF STATE (ADMINISTRATIVE COURT, 28 MARCH 2006, UNREPORTED)}

The facts of Morris were that the claimant and her daughter came to the United Kingdom from Mauritius and were given leave to enter as visitors. When their leave to remain expired, the claimant applied for a British passport on the basis that she was a British citizen by descent. That status was subsequently recognised and she obtained a British passport, while her daughter was not thought eligible for British citizenship and remained a citizen of Mauritius alone. The claimant subsequently applied to the defendant council for accommodation under the Housing Act 1996. That application was refused on the basis that the claimant did not have a 'priority need for accommodation'. The council, relying on s 185(4) of the Housing Act 1996, subsequently confirmed its decision.

Under s 189 of the Housing Act 1996, a person with dependent children had a 'priority need for accommodation'. However, s 185(4) prevented an otherwise eligible applicant from relying on a person subject to immigration control to bring him/her within the class of persons with dependent children. In other words, if the claimant's daughter had been British, the claimant would have had a 'priority need for accommodation'. As the claimant's daughter was not British, the claimant did not have a 'priority need for accommodation'.

On 14 October 2005, the Court of Appeal declared that s 185(4) was incompatible with the right under article 14 of the Convention to enjoy without discrimination the right under article 8 of the Convention to respect for home and family life to the extent that it required a dependent child of a British citizen, if both were habitually resident in the United Kingdom, to be disregarded when determining whether the British citizen had a priority need for accommodation, when that child was subject to immigration control.

The government's response to Morris took some time to develop. On 3 March 2006, the Office of the Deputy Prime Minister informed parliament's Joint Committee on Human Rights ('JCHR') that the government had decided not to appeal the decision. ${ }^{110}$ On 28 March 2006, the Administrative Court made a declaration by consent in Gabaj ${ }^{111}$ that s 185(4) was incompatible with the Convention, albeit in slightly different terms to the declaration in

\footnotetext{
${ }^{110}$ Joint Committee on Human Rights, UK Parliament, Twenty Third Report (2006) app 4 (Letter from Alan Edwards to the JCHR dated 2 March 2006).

${ }^{111}$ Ibid (Letter from Alan Edwards to the JCHR dated 20 April 2006). See also Ministry of Justice (n 22) 40.
} 
Morris. On 27 June 2006, the Minister for Housing and Planning, Yvette Cooper, advised the JCHR that the government intended to remedy the incompatibility as quickly as possible. ${ }^{12}$

Schedule 15 of the Housing and Regeneration Act 2008 introduced amendments to the Housing Act 1996 that meant that s 185(4) would no longer apply to British citizens. ${ }^{113}$ Accordingly, a British citizen with a dependent child who applied for housing, like Mrs Morris, would have a 'priority need for accommodation' even if that child was not a British citizen and subject to immigration control. The housing authority to which the application was made would discharge its duty to the applicant, not by offering long-term social housing, but by arranging an offer of accommodation in the private rental sector. The policy concerns of the government and the purpose of Schedule 15 were explained by the UnderSecretary of State for Communities and Local Government, Iain Wright, when the Commons was considering the amendments:

"This is a complex area of law, but in summary, the issue at stake is what help British citizens whose household includes members with different immigration status should get if they become homeless. The amendments will ensure that in future, households in those circumstances will be provided with suitable housing, while continuing to ensure that people from abroad with no claim to UK public resources cannot confer entitlement to long-term social housing." 114

The amendments were passed by parliament without dissent. ${ }^{115}$

Although Morris posed 'particularly difficult' policy problems, ${ }^{116}$ there are reasons to believe that the parliament was comfortable with the ultimate outcome as expressed in the amendments to the Housing Act 1996. Firstly, the government naturally accepted that British citizens had to be provided with some form of housing assistance if they became homeless through no fault of

\footnotetext{
${ }^{112}$ Ibid (Letter from Yvette Cooper to the JCHR dated 27 June 2006).

${ }^{113}$ Section 185(4) was also amended so that it would not apply to European Economic Area nationals and Commonwealth citizens with a right of abode in the United Kingdom.

${ }^{114}$ HC Deb (Grand Committee), 21 July 2008, vol 479, col 610.

115 The amendments were introduced in Committee on 23 June 2008 (HL Deb (Grand Committee) 23 June 2008, vol 702, col GC495-560); they were agreed to in the House of Lords on the third reading of the Housing and Regeneration Bill on 17 July 2008 (HL Deb 17 July 2002, vol 637, col 1322- 88) and agreed to in the House of Commons on 21 July 2008 (HC Deb 21 July 2008, vol 479, col 575-621).

${ }^{116}$ HL Deb 9 July 2008, vol 703, col 821 (Baroness Andrews).
} 


\section{DIALOGUE AND DECLARATIONS OF INCOMPATIBILITY UNDER SECTION 4 OF THE HUMAN RIGHTS ACT 1998}

their own. ${ }^{117}$ Secondly, as noted above, the amendments were agreed to without dissent. Thirdly, it seems unlikely that the amendments would have resulted in significant additional expenditure for the government. Only a small number of people were affected by the operation of $\mathrm{s} 185(4) .{ }^{118}$ The amendments did not result in migrants obtaining access to scarce and valuable social housing. Accordingly, there is good cause to think that Morris did provoke an exchange of ideas about rights pursuant to which policy goals were revised but not blocked.

\section{3. $R$ (CLIFT) V SECRETARY OF STATE FOR THE HOME DEPARTMENT [2006] UKHL 54, [2007] 1 AC 484}

The claimants were foreign citizens who had been sentenced to lengthy terms of imprisonment and made subject to deportation orders. By virtue of ss 46(1) and 50(2) of the Criminal Justice Act 1991, the Parole Board had no power to recommend the early release on licence of long-term prisoners subject to deportation orders and the decision was at the discretion of the Home Secretary. The claimants each made representations for early release but the Home Secretary decided not to order their release. The claimants sought judicial review of the Home Secretary's decisions as being contrary to articles 5 and 14 of the Convention ${ }^{119}$ in that they were treated differently from long-term prisoners who were not subject to deportation because those prisoners were entitled to the benefit of a referral to the Parole Board. The judge at first instance allowed the claims but was overturned by the Court of Appeal.

On appeal, the Judicial Committee of the House of Lords held that differential treatment afforded to prisoners liable to deportation by having their release dates determined by the Secretary of State could not be

117 HL Deb (Grand Committee) 23 June 2008, vol 702, col GC524 (Baroness Andrews).

${ }^{118}$ HL Deb (n 116) col 820 (Baroness Andrews).

${ }^{119}$ Convention (n 7).

Article 5 relevantly provides as follows:

1. Everyone has the right to liberty and security of person. No one shall be deprived of his liberty save in the following cases and in accordance with a procedure prescribed by law:

(a) the lawful detention of a person after conviction by a competent court;...

4. Everyone who is deprived of his liberty by arrest or detention shall be entitled to take proceedings by which the lawfulness of his detention shall be decided speedily by a court and his release ordered if the detention is not lawful.

Article 14 relevantly provides as follows:

The enjoyment of the rights and freedoms set forth in this Convention shall be secured without discrimination on any ground such as...national or social origin. 
objectively justified, given the Parole Board's ability to make such determinations. Accordingly, a declaration would be made that ss 46(1) and 50 (2) were incompatible with article 14 , read with article 5 , to the extent that they prevented prisoners liable for removal having their cases reviewed by the Parole Board in the same manner as other long-term prisoners.

By the time the matter was heard by the House of Lords, ss 46(1) and 50(2) had been repealed and replaced by the Criminal Justice Act 2003. But they continued to apply to offences committed before 4 April 2005 pursuant to the Criminal Justice Act 2003 (Commencement No 8 and Transitional and Saving Provisions) Order 2005 so they continued to apply to the claimants. Section 27 of the Criminal Justice and Immigration Act 2008 amended the Criminal Justice Act 1991 to remove the incompatibility in transitional cases.

Section 27 seems to have been enacted without difficulty or controversy. Although the Criminal Justice and Immigration Act 2008 had a long passage through parliament, the wording of s 27 did not change from the time that it was first presented. ${ }^{120}$ The Public Bill Committee appointed to consider the Criminal Justice and Immigration Bill agreed, without dissent, that it should form part of the legislation. ${ }^{121}$ The JCHR concurred, saying that it was a 'simple' remedy to a 'straightforward legal problem'.

\section{SMITH V SCOTT [2007] CSIH 9, 2007 SC 345}

This case concerned the incapacity of convicted prisoners to vote pursuant to s 3 of the Representation of the People Act 1983, which relevantly provides as follows:

"A convicted person during the time that he is detained in a penal institution in pursuance of his sentence... is legally incapable of voting at any parliamentary or local government election."

On 6 October 2005, the ECtHR held in Hirst v United Kingdom (No 2) ${ }^{123}$ that s 3 violated article 3 of the First Protocol to the Convention. Article 3 provides as follows:

"The High Contracting Parties undertake to hold free elections at reasonable intervals by secret ballot, under conditions which will

${ }^{120}$ Criminal Justice and Immigration Bill 2007 (UK) cl 15.

${ }^{121}$ PBC Deb 21 November 2007, vol 467, col 355-363.

122 Joint Committee on Human Rights, Thirty First Report (2008) [107].

123 (2006) 42 EHRR 41. 


\section{DIALOGUE AND DECLARATIONS OF INCOMPATIBILITY UNDER SECTION 4 OF THE HUMAN RIGHTS ACT 1998}

ensure the free expression of the opinion of the people in the choice of the legislature."

For present purposes it is important to note that the ECtHR has interpreted article 3 as conferring individual suffrage rights and has held that the undertaking given by the High Contracting Parties (which obviously includes the United Kingdom) obliges them to take positive steps to guarantee those rights. ${ }^{124}$

On 2 February 2006, the British government indicated that, as a result of the Hirst decision, it would undertake a public consultation in relation to prisoners' voting rights. ${ }^{125}$

On 14 February 2006, the Registration Appeal Court (in effect, the Scottish Court of Session) first began to hear Mr Smith's appeal. Mr Smith was a convicted drug dealer whose application to be included in the register of electors had been refused pursuant to $\mathrm{s} 3$ of the Representation of the People Act 1983. The time allocated for the appeal was insufficient and it was adjourned to a later date.

On 14 December 2006, the Department of Constitutional Affairs published a consultation document, which set out the principles of prisoner enfranchisement and the options available to the United Kingdom. ${ }^{126}$

On 11 January 2007, the Registration Appeal Court reconvened for the final time on Mr Smith's appeal. During the course of the appeal, counsel for the Secretary of State for Scotland informed the court that the Secretary of State fully accepted the Hirst decision. ${ }^{127}$ The Secretary of State submitted that a declaration was unnecessary as the government was already aware that $\mathrm{s}$ 3 was not Convention-compliant and action was being taken to remedy that situation. ${ }^{128}$

On 24 January 2007, the court delivered its judgment in which it noted that, although the government had published its consultation document, the issue of prisoners' voting rights had not been resolved despite having been in

${ }^{124}$ Sophie Briant, 'Dialogue, Diplomacy and Defiance: Prisoners' Voting Rights at Home and in Strasbourg' [2011] EHRLR 243, 244 citing Mathieu-Mohin and Clerfayt $v$ Belgium (Series A no. 113), judgment of 2 March 1987, 22-23.

${ }^{125}$ Smith v Scott 2007 SC 345, 360-361.

${ }^{126}$ Steve Foster, 'The Long and Winding Road: the Battle for the Prisoner's Right to Vote' (2011) 16(1) Cov LJ 19, 21 citing Department of Constitutional Affairs (UK), 'Voting Rights of Convicted Prisoners Detained Within the United Kingdom - The UK Government's Response to the Grand Chamber of the European Court of Human Rights' Judgment in Hirst v United Kingdom' CP29/06 (2006).

${ }^{127}$ Smith v Scott 2007 SC 345, 349.

${ }^{128}$ Ibid 364. 
the public arena for a long time. ${ }^{129}$ In those circumstances and in light of the fact that the Scottish parliamentary election would be held in May 2007, the court decided that it would make a declaration that s 3 was incompatible with article 3 of the First Protocol to the Convention. ${ }^{130}$

The declaration of the Scottish court produced no response in the British parliament.

On 27 March 2007, the Lord Chancellor, Lord Falconer, informed the JCHR that the government did not believe that the declaration required urgent action because the judgment did not establish any new principle beyond that established in Hirst. The Lord Chancellor also noted that the government's consultation process was still underway. ${ }^{131}$

Thereafter, it is fair to say that the Labour government relied upon the consultation process to delay law reform on the topic for the remainder of its time in office. ${ }^{132}$ The new Conservative/Liberal Democrat government, elected in May 2010, had no real desire to amend the law either. The politically popular view was enunciated by Prime Minister David Cameron in November 2010: 'Frankly, when people commit a crime and go to prison, they should lose their rights, including the right to vote'. ${ }^{133}$

Eventually, the issue came before the ECtHR again in Scoppola v Italy (No 3) ${ }^{134}$, a case concerning prisoner voting rights in which the United Kingdom was given leave to intervene. The United Kingdom submitted that the findings in Hirst were wrong and that the ECtHR should revisit its decision. ${ }^{135}$ On 22 May 2012, the ECtHR rejected that submission and reaffirmed the principles set down in Hirst. ${ }^{136}$

The result of Scoppola was that the United Kingdom government was required to provide the ECtHR with proposals that satisfied article 3 of the First Protocol within 6 months of the judgment. ${ }^{137}$

On 22 November 2012, the British government published the Voting Eligibility (Prisoners) Draft Bill and announced it would be considered by a joint committee of both houses of parliament. The draft bill set out 3 different potential approaches for the committee to consider. The first would enable

\footnotetext{
${ }^{129}$ Ibid 364-365.

130 Ibid 365.

131 Joint Committee on Human Rights, Sixteenth Report (2007), app 13.

132 Colin Murray, 'Playing for Time: Prisoner Disenfranchisement under the ECHR after Hirst v United Kingdom’ (2011) 22 KLJ 309, 310.

${ }^{133}$ Ibid citing HC Deb 3 November 2010, vol 517, col 921.

134 (2013) 56 EHRR 19.

135 Ibid 677.

${ }^{136}$ Ibid 681.

137 Steve Foster, 'Prisoners' voting rights and the ECHR: still hazy after all these years' (2012) 17(1) Cov LJ 75, 80.
} 


\section{DIALOGUE AND DECLARATIONS OF INCOMPATIBILITY UNDER SECTION 4 OF THE HUMAN RIGHTS ACT 1998}

prisoners sentenced to less than 4 years to vote. The second would limit the vote to prisoners sentenced to 6 months or less. The third approach would continue the ban on prisoner voting. ${ }^{138}$

As at today's date, the joint committee has not been appointed, the issue has not been resolved and there is still much drama to be played out. Prime Minister Cameron has stated very clearly that prisoners will not get the vote under his government. ${ }^{139}$ The Labour Party has proclaimed its opposition to prisoner enfranchisement too. ${ }^{140}$ The current Home Secretary, Theresa May, has indicated that the next Conservative government will scrap the $H R A$ and may leave the Convention altogether. ${ }^{141}$ Against this backdrop, it has been reported $^{142}$ that the UK Supreme Court will hear an appeal in June 2013 by a convicted murderer, George McGeoch, who has not been allowed to add his name to the electoral register. ${ }^{143}$

Whatever the eventual outcome, it seems fairly clear that the declaration in Smith did not result in an exchange of views between parliament and the judiciary about the voting rights of prisoners. Due to the decision in Hirst, consideration of that issue was well underway by the time the judgment in Smith was handed down. Furthermore, there was no parliamentary response to the declaration. It was not a case of parliament considering and then rejecting the Registration Appeal Court's opinion: it was more or less ignored.

Parliament's failure to respond to the declaration in Smith raises some interesting implications for dialogue theory. It is evidence that a declaration might not have the practical effect of compelling parliament to comply with the views of the judiciary. How could parliament ignore the declaration in

${ }^{138}$ HC Deb 22 November 2012, vol 553, col 746 (Chris Grayling).

139 Graeme Wilson, 'Prisoners won't get the Vote, says PM' The Sun (London) 25 October 2012.

${ }^{140}$ In response to the announcement of 22 November 2012, the shadow Justice Minister, Sadiq Khan, revealed that the Labour government's assurances to the Registration Appeal Court in Smith v Scott may not have been entirely accurate: 'The Labour government disagreed with the Court's decision [in Hirst]. It is not, and never has been, Labour's position to give prisoners the vote. That is why we appealed the decision and continued to challenge it until we lost office': see HC Deb (n 138) col 747.

141 Theresa May, 'Victory 2015' (speech delivered to Conservative Home conference, London, 9 March 2013).

${ }^{142}$ Owen Bowcott, 'Britain 'painted itself into a corner' on prisoner votes: Human Rights Chief says UK is setting bad example' The Guardian (London) 16 July 2012; Owen Bowcott, 'Judge defends court role over terror suspects: Ministers and supreme court chief at odds over use of human rights laws' The Guardian (London) 5 March 2013.

${ }^{143}$ McGeoch v Lord President of the Council [2011] CSIH 67, 2012 SC 410. 
Smith yet be forced to comply with the ruling in Belmarsh? The answer probably lies in the different circumstances surrounding the two cases:

a) Previous ECtHR decision. By the time Smith was handed down, parliament was already dealing with the binding decision of the ECtHR in Hirst. Smith was merely a non-binding (in the strict legal sense) affirmation of Hirst. By contrast, Belmarsh was the sole judicial authority as to whether the government's detention scheme was compatible with human rights.

b) Public support for the legislation in question. The enfranchisement of prisoners had almost no popular support. By contrast, the detention system introduced by the Anti-terrorism, Crime and Security Act 2001 was controversial and many people supported its abolition.

c) Public awareness of the declaration. The Belmarsh decision was highly-publicised in the media. By contrast, Smith was a relatively obscure decision of a Scottish court.

d) Public respect for the declaration. Belmarsh was a ruling of the highest court in the United Kingdom. By contrast, the Registration Appeal Court in Smith effectively followed a previous ruling of an unpopular European court.

Taken together, these factors probably made it relatively easier, from a political standpoint, for the government to effectively disregard Smith as compared to Belmarsh.

As noted above, at present it is unclear as to whether parliament will eventually give some prisoners the right to vote. A decision by the Supreme Court in Mr McGeoch's favour may force parliament's hand, much as the declaration in Belmarsh did. ${ }^{144}$ The issue of prisoner enfranchisement may end up playing a decisive role, not only in determining whether parliament can have the final say under the HRA, but in the very future of that Act.

\footnotetext{
${ }^{144}$ If the decision by the Court of Appeal in $R$ (Chester) $v$ Secretary of State for Justice [2010] EWCA Civ 1439, [2011] 1 WLR 1436 is any indicator, it is unlikely that the Supreme Court will press the government. In Chester, the appellant sought the same declaration as was granted in Smith. In dismissing the appeal, the Court of Appeal noted that the government's choices were 'delicate', 'difficult' and 'a political responsibility’: see Chester [2011] 1 WLR 1436, 1449.
} 


\section{5. $R$ (BAIAI) V SECRETARY OF STATE FOR THE HOME DEPARTMENT (NOS 1 AND 2) [2008] UKHL 53, [2009] 1 AC 287}

In the United Kingdom, non-European Economic Area nationals are subject to immigration control and require leave to enter or remain in the country. Section 19 of the Asylum and Immigration (Treatment of Claimants, etc) Act 2004, together with the Immigration (Procedure for Marriage) Regulations 2005, introduced a regime under which non-EEA nationals had to apply to the Home Secretary for a certificate of approval to marry if they wished to enter into a marriage otherwise than in accordance with the rites of the Church of England. The Home Secretary's policy was that, in order to obtain a certificate, an applicant had to have valid leave to enter or remain in the United Kingdom for more than six months (and more than three months of that leave had to be unexpired at the time of the application), or exceptionally compelling compassionate grounds.

The claimants were refused certificates. They sought judicial review and a declaration of incompatibility on the grounds that the s 19 regime and the Home Secretary's policy were incompatible with the right to marry protected by article 12 of the Convention. The Home Secretary maintained that the regime was necessary in order to avoid the abuse of immigration rights by marriages of convenience.

The Judicial Committee of the House of Lords found that the conditions set out in the Home Secretary's policy, though relevant to immigration status, had no relevance to the genuineness of a proposed marriage, which was the only relevant criterion for determining whether permission should be given. Their Lordships held that, since the effect of the policy, subject to the discretionary compassionate exception, was to impose a blanket prohibition on exercise of the right to marry by all those within the specified categories irrespective of whether the parties' proposed marriages were ones of convenience, the scheme represented a disproportionate interference with the right to marry. The scheme violated article 12 to that extent and a declaration was made accordingly.

The certificate of approval scheme was abolished by the Asylum and Immigration (Treatment of Claimants, etc) Act 2004 (Remedial) Order 2011. The Order was approved by the House of Commons without debate. ${ }^{145}$ In the House of Lords, the Minister of State for Security and Counter Terrorism, Baroness Neville-Jones, moved that the Order be approved, stating:

${ }^{145}$ HC Deb 30 March 2011, vol 526, col 485. 
"The Government want to bring this order into force subject to your Lordships' agreement. We are doing so for two reasons. First, the domestic courts have declared that the scheme is incompatible with the European Convention on Human Rights. Abolishing the scheme will remove this incompatibility. Secondly, changes made following rulings from the domestic courts have weakened the scheme and the Government do not consider it any longer to be an effective method of dealing with sham marriages."

Lord Avebury indicated that the Liberal Democrat Party welcomed the Order. ${ }^{147}$ Lord Rosser signalled that the Labour Party also supported the Order 'in light of the court judgments' but stated that he had a number of concerns about whether the government could continue to restrict sham marriages. ${ }^{148} \mathrm{In}$ response to Lord Rosser, Baroness Neville-Jones declared that:

"Although there is some anxiety in the House, which I share, about our ability to control the situation, we will be monitoring it carefully and making our best efforts to ensure that [the sham marriage] route is not used. I hope that the House will feel it necessary to abolish the scheme and, on the basis of the Government putting in place the best methods that we can to control this, approve the order."149

The House of Lords duly approved the Order.

As all sides of British politics appeared to accept that the abolition of the certificate of approval scheme was necessary, Baiai may very well have produced a real exchange of views about human rights between the judiciary and parliament.

\section{6. $R$ (WRIGHT) V SECRETARY OF STATE FOR HEALTH [2009] UKHL 3, [2009] 1 AC 739}

The claimants were care workers who were referred to the Health Secretary under s 82(1) of the Care Standards Act 2000, which made provision for keeping a list of people considered unsuitable to work with vulnerable adults. Pending the determination of each reference, the Health Secretary provisionally included the claimants' names in the list pursuant to $\mathrm{s}$ 82(4)(b), which made no provision for first according them a hearing.

\footnotetext{
${ }^{146}$ HL Deb 4 April 2011, vol 726, col 1603.

${ }^{147}$ Ibid col 1605.

${ }^{148}$ Ibid col 1607-1608.

${ }^{149}$ Ibid col 1612.
} 


\section{DIALOGUE AND DECLARATIONS OF INCOMPATIBILITY UNDER SECTION 4 OF THE HUMAN RIGHTS ACT 1998}

The Judicial Committee of the House of Lords held that, given the possibility that provisional listing under s 82(4)(b) could result in irreparable damage to a person's employment or prospects of employment in the care sector, the denial of an opportunity to answer allegations before being listed meant that s 82(4)(b) contravened the right to a fair hearing under article 6(1) of the Convention. The House of Lords further held that the listing of a person on suspicion of such serious misconduct as to indicate that he or she posed a risk to vulnerable adults could result in stigma so great as to constitute an interference with the right to respect for private life under article 8 of the Convention. Accordingly, their Lordships made a declaration that s 82(4) was incompatible with articles 6 and 8 of the Convention.

The day before the judgment was handed down, the government announced that the Independent Safeguarding Authority (ISA) had assumed full responsibility for deciding whether a person should be barred from working with children and vulnerable adults. ${ }^{150}$ This new barring system was a completely different system to that considered in Wright. Indeed, the existence of the new scheme was referred to in the judgment but the Law Lords noted that they had 'not heard argument upon whether or not that scheme is compatible with the Convention rights as the question does not arise on these appeals'. ${ }^{151}$

The new vetting and barring system was established in response to findings of the Bichard Inquiry, which had been set up in 2004 following the conviction of Ian Huntley, a school caretaker, for the murders of two schoolgirls. ${ }^{152}$ The Inquiry report recommended, amongst other things, that a registration scheme should be established for those wishing to work with children or vulnerable adults. The Safeguarding Vulnerable Groups Act 2006 provided for such a scheme, maintained by the ISA. ${ }^{153}$

In short, the abolition of the old scheme and the introduction of the new vetting and barring scheme were not instigated by the declaration in Wright.

\section{7. $R$ (F AND THOMPSON) V SECRETARY OF STATE FOR THE HOME DEPARTMENT [2010] UKSC 17, [2011] 1 AC 331}

The claimants were sex offenders. By virtue of the nature of their offences and the length of their sentences, they became automatically subject for an

\footnotetext{
${ }^{150}$ HC Deb 20 January 2009, vol 486, col 23WS.

151 [2009] 1 AC 739, 755.

152 After Mr Huntley was convicted, it was revealed that, although he had been investigated for sexual offences, he had been able to work at a school because none of those investigations had resulted in a conviction.

${ }^{153}$ Explanatory Notes to the Protection of Freedoms Act 2012 (UK), 11.
} 
indefinite period to the notification requirements in ss $82-86$ of the Sexual Offences Act 2003. By these requirements, an offender has to inform the police of certain personal details and by the Sexual Offences Act 2003 (Travel Notification Requirements) Regulations 2004, made pursuant to s 86, an offender has to inform the police of the details of foreign travel plans. These notification requirements are what are known colloquially as the 'sex offenders register'. ${ }^{154}$

The Divisional Court of the Queen's Bench Division made a declaration that the absence of any mechanism for review of the notification requirements in the 2003 Act was a disproportionate interference with the right to respect for private and family life guaranteed by article 8 of the Convention. ${ }^{155}$ On appeal, the decision was upheld by the Court of Appeal ${ }^{156}$ and the Supreme Court.

The Supreme Court's judgment was handed down on 21 April 2010. The government's response took some time to develop but, when it came, it was ferocious.

On 16 February 2011, the Home Secretary, Ms May, made a statement in the House of Commons in which she declared that the government was 'disappointed and appalled' by the decision in $F$ and Thompson. She proclaimed that the government would make the 'minimum possible changes to the law in order to comply with the ruling,. ${ }^{157}$

Prime Minister Cameron also declared that he was 'appalled' by the decision, stating how 'completely offensive' it was to 'once again...have a ruling by a court that flies in the face of common sense'. ${ }^{158}$

Interestingly, the Home Secretary asserted that:

"I would far rather not have to stand here saying that we have to make a change to the sex offenders register, but we do have to make a change." 159

154 Terry Thomas and David Thompson, 'Applications to Come off the UK Sex Offender Register: the Position After F and Thompson v. Home Office 2010' (2012) 51(3) Howard Journal 274 at 274.

${ }_{155}^{150}$ [2008] EWHC 3170, [2009] 2 Cr App R (S) 47.

156 [2009] EWCA Civ 792, [2010] 1 All ER 1024.

${ }_{158}^{15}$ HC Deb 16 February 2011, vol 523, col 959.

${ }^{158}$ Ibid col 955. Other government members also voiced their displeasure with $F$ and Thompson: see 'MP slams sex offender ruling' Essex Chronicle (Chelmsford), 24 February 2011; 'PM “appalled” by ruling on sex register' Coventry Telegraph (UK), 17 February 2011.

${ }^{159}$ HC Deb (n 157) col 961. 


\section{DIALOGUE AND DECLARATIONS OF INCOMPATIBILITY UNDER SECTION 4 OF THE HUMAN RIGHTS ACT 1998}

After this assertion was made, Labour MP Jack Straw put the following proposition to Ms May:

"[Will] she confirm that under section 4 of the Human Rights Act 1998 there is absolutely no obligation on her or the House to change the law one bit? All the Court did was to issue a declaration of incompatibility and section 4 makes it absolutely clear that any decision following that is a matter for the sovereign Parliament. It would be entirely lawful for the House and her to say that the existing regime will continue without any amendment."160

The Home Secretary responded to that proposition in the following terms:

"The right hon. Gentleman makes a point about the application of the Human Rights Act and the European convention on human rights and about Parliament having the final decision about what should happen. In this case, Parliament will have the final decision on what happens." 161

It is probably fair to say that the Home Secretary fudged the issue. If she had been willing to answer the question directly, her answer may have been along the following lines, 'It is politically easier for the government to blame the judiciary and make minor changes to the legislation than it is to leave the legislation as it stands and provoke a constitutional crisis'. ${ }^{162}$

Of course, there may very well have been other reasons why the government thought it necessary to amend the legislation. When the amending instrument was eventually placed before parliament (the Sexual Offences Act 2003 (Remedial) Order 2012), the Conservative peer, Baroness Stowell of Beeston, stated that:

"Our constitutional arrangements are such that when the highest court of the land identifies an incompatibility with the European Convention on Human Rights, the Government of the day, whoever is in power, take remedial action. This is for various reasons, not the least of which is to ensure that the Government are not left vulnerable to further legal

\footnotetext{
${ }^{160}$ Ibid col 963.

161 Ibid col 963 .

${ }^{162}$ In this context, see Vernon Bogdanor, 'Who decides when MPs and courts collide?: Britain is fast approach a crisis of authority that only a written constitution can resolve' The Times (London), 25 May 2011, 22.
} 
proceedings, potentially involving millions of pounds of taxpayers' money." 163

In other words, the threat of proceedings in the ECtHR (which the government clearly could not win) was a powerful incentive to amend the legislation.

The Sexual Offences Act 2003 (Remedial) Order 2012 enabled sex offenders to apply to the police for a review of whether their notification requirements should cease. The application could only be made once a fixed period of time had expired following the offender's release from custody: for adults this period was 15 years and for children it was 8 years. Offenders could appeal from the police decision to the magistrates' court but the onus would be on them to demonstrate that they no longer posed a risk to the community.

It is unclear whether this new policy was a distortion of the old (that is, less effective but more easily defensible before the courts). ${ }^{164}$ The Labour Party certainly had serious reservations about the costs involved in allowing offenders to apply for a review and the risk to the community in permitting offenders to come off the register. They refused to support the new policy. ${ }^{165}$ Unfortunately, sex offences committed by persons released from the register will be a prerequisite to determining whether the Labour Party's stance was correct.

It is possible that the government's rage over $F$ and Thompson was merely confected. The outbursts from the Prime Minister and the Home Secretary occurred well after the decision was handed down. The government did, of course, theoretically have the power to ignore $F$ and Thompson and the Home Secretary did concede that parliament would make the final decision on the appropriate policy. If the government had chosen not to amend the legislation, the Labour Party may very well have supported that position.

It seems more likely, however, in light of Ms May's subsequent declaration that the next Conservative government would scrap the HRA, ${ }^{166}$ that the frustration expressed by Conservative politicians about $F$ and Thompson was genuine. The Conservatives were probably confronted with a conundrum similar to that faced by the Labour government after the Anderson

\footnotetext{
${ }^{163}$ HL Deb 5 July 2012, vol 738, col 875.

${ }^{164}$ Manfredi and Kelly (n 107) 522.

${ }^{165}$ HL Deb (n 163) col 879-883 (Baroness Smith). See also the comments of Diana Johnson in HC Deb, Eighth Delegated Legislation Committee Debates, 19 June 2012. $<$ http://www.publications.parliament.uk/pa/cm201213/cmgeneral/deleg8/120619/120 619s01.htm>.

${ }^{166}$ May (n 141).
} 


\section{DIALOGUE AND DECLARATIONS OF INCOMPATIBILITY UNDER SECTION 4 OF THE HUMAN RIGHTS ACT 1998}

decision. They did not want to afford criminals additional rights but, by the same token, they did not want to come into direct conflict with the highest court in the nation. Ignoring the declaration would simply mean that the matter would be taken to the ECtHR where the government would inevitably lose.

There may have been another factor that influenced the policy outcome: the fact that the government was a coalition between the Conservative Party and the Liberal Democrat Party. The Liberal Democrats were probably much more inclined to accept that the government should follow the Supreme Court's ruling than many Conservatives were. ${ }^{167}$ Amendment of the legislation may have been a price that Conservatives such as the Prime Minister and the Home Secretary were willing to pay in order to keep the coalition intact.

The making of the Sexual Offences Act 2003 (Remedial) Order 2012 was about raw politics; it had little to do with principle. Neither the Conservative Party nor the Labour Party really thought that allowing sex offenders an opportunity to come off the register was a good idea. It would be far-fetched to describe the process as having involved a genuine exchange of opinions about rights. Like Anderson, if there was any flow of information, it was closer to a monologue, judges doing the talking and legislatures the listening, than a dialogue.

\section{8. $R$ (ROYAL COLLEGE OF NURSING) V SECRETARY OF STATE FOR THE HOME DEPARTMENT [2010] EWHC 2761 (ADMIN); [2011] PTSR 1193}

The Safeguarding Vulnerable Groups Act 2006 provided for a registration scheme for those wishing to work with children or vulnerable adults, which was maintained by the ISA.

Under the scheme, persons convicted of or cautioned for a serious sexual offence would be placed on the barred lists with no opportunity to make representations as to why their inclusion might be unwarranted. ${ }^{168}$ Pursuant to

${ }^{167}$ See eg Libby Brooks, 'This is not the way to keep us safe from sex offenders: David Cameron's "stand against paedophiles" is more to do with ditching the Human Rights Act than protecting victims' The Guardian (London), 18 February 2011; Allegra Stratton, 'Nick Clegg tells Lib Dems: power means accepting unpopularity: More than 1,000 police officers on duty or standby at conference, ready for mass protests' The Guardian (London), 11 March 2011; see also the comments of the Liberal Democrat peer, Lord Lester: HL Deb 5 July 2012, vol 738, col 884-6.

${ }^{168}$ See Ralph Sandland 'Policing Care in the House of Lords' [2009] J Mental Health L 171, 174-175. 
paragraph 8 of Schedule 3 to the Act (when read with the regulations ${ }^{169}$ ), persons convicted of or cautioned for specified offences that were less grave than the aforementioned serious sexual offences would also be automatically placed on the barred lists but had the right to make representations as to why they should be removed. It is the latter category with which the Royal College of Nursing case was concerned.

The facts of Royal College of Nursing were that the ISA placed the second to fourth claimant nurses on the barred lists after having been informed that they had been cautioned for relatively minor offences. Their names were subsequently removed but the nurses suffered a significant loss of wages during the periods when they had been unable to work. The first claimant, a body representing the interests of the nursing profession, and the nurses challenged the lawfulness of the scheme.

On 10 November 2010, Mr Justice Wyn Williams held, after considering the decision in Wright, that the nurses' inability to make representations in advance of listing was a breach of article 6 of the Convention. His Honour also found that the scheme gave rise to potential breaches of article 8 . Accordingly, his Honour declared that paragraph 8 of Schedule 3 to the Act was incompatible with articles 6 and 8 of the Convention.

By the time that the case was argued before Mr Justice Wyn Williams, the new Conservative/Liberal Democrat government had already announced that the vetting and barring scheme would be reviewed and remodelled. ${ }^{170}$ In the review report dated February 2011, the government stated:

"Following a recent judicial review brought by the Royal College of Nurses, the "autobar with representations" element of the scheme has been found by the courts not to be compatible with human rights obligations, to the extent that a person is barred before having any opportunity to make representations against the decision. This decision has been accepted by Ministers and it follows that this process must be changed in any new scheme."171

The process was changed by s 67 of the Protection of Freedoms Act 2012. Under the new process, the ISA was required to seek representations from an

\footnotetext{
169 Safeguarding Vulnerable Groups Act 2006 (Prescribed Criteria and Miscellaneous Provisions) Regulations 2009 (UK), sch (reg 6 and para 4).

${ }^{170}$ Explanatory Notes to the Protection of Freedoms Act 2012 (UK), 11. Mr Justice Wyn Williams referred to the review in the course of his judgment: [2011] PTSR 1193, 1228.

${ }^{171}$ Home Office (UK), Vetting and Barring Scheme Remodelling Review - Report and Recommendations, 11 February 2011, 25.
} 


\section{DIALOGUE AND DECLARATIONS OF INCOMPATIBILITY UNDER SECTION 4 OF THE HUMAN RIGHTS ACT 1998}

individual who had committed one of those specified offences less grave than a serious sexual offence prior to reaching a decision on whether to place that person on the barred lists. If no representations were received within the prescribed time period, the ISA was required to place the individual on the lists.

The need to amend the Act was, as the review report indicated, accepted by the government. The new process was uncontroversial and proceeded unchallenged through parliament. ${ }^{172}$ Accordingly, it can be concluded that Royal College of Nursing probably did result in an exchange of views about rights between the judiciary and parliament pursuant to which policy may very well have been constructively amended.

\section{CONCLUSIONS}

Of the 18 cases in which declarations of incompatibility have been finalised, 17 have resulted in change to legislation for one reason or another. The only case in which the making of a declaration of incompatibility pursuant to s 4 of the HRA has not resulted in legislative change is Smith $v$ Scott. The issue of whether prisoners will get the vote should be decided, at the latest, by the outcome of the 2015 general election. That election is also likely to be critical in determining the future of the HRA.

Of the 17 cases resulting in legislative change, it could only rightly be argued that 8 of them involved a process of 'dialogue' between the courts, parliament and the executive (that is, there was an exchange of ideas about human rights pursuant to which policy goals were revised, but not blocked, following the judicial decision):

\section{- $R(H) v$ London North and East Region Mental Health Review Tribunal}

-International Transport Roth GmbH v Secretary of State for the Home Department

$-R(D) v$ Secretary of State for the Home Department

- $R$ (Morris) v Westminster City Council (No 3)

$-R$ (Gabaj) v First Secretary of State

$-R$ (Clift) $v$ Secretary of State for the Home Department

$-R$ (Baiai) $v$ Secretary of State for the Home Department (Nos 1 and 2)

$-R$ (Royal College of Nursing) $v$ Secretary of State for the Home Department

172 The reading debates can be found at HC Deb 1 March 2011, vol 524, col 205-271; HC Deb 11 October 2011, vol 533, col 281-301; HL Deb 8 November 2011, vol 732, col 167-228; HL Deb, 12 March 2012, vol 736, col 15-69. 
Of those 8 cases, 2 dealt with the exactly the same statutory provision: Morris and Gabaj. It should also be noted that the declaration in $D$ had no real effect because the new legislation simply accorded with what the government's practice had always been.

It could not be rightly argued that the other 9 cases involved a process of 'dialogue'.

In 6 of those 9 cases, the process of amending the impugned legislation was well underway, or indeed completed, by the time the court made the declaration of incompatibility:

-Re an Application for Judicial Review by McR

-Blood and Tarbuck $v$ Secretary of State for Health

- Bellinger $v$ Bellinger

$-R(M) v$ Secretary of State for Health

$-R$ (Wilkinson) v Inland Revenue Commissioners

$\bullet R$ (Wright) $v$ Secretary of State for Health

In these 6 cases, the making of a declaration did not cause the legislative change. There could not have been 'dialogue' because the policy goals were revised before the judicial decision, not after.

The remaining 3 cases were the ones that attracted the most public interest:

\section{- $R$ (Anderson) $v$ Secretary of State for the Home Department}

- A v Secretary of State for the Home Department ('Belmarsh')

$\bullet R$ ( $F$ and Thompson) $v$ Secretary of State for the Home Department

In each of these 3 cases, the making of the declaration was a direct cause of the legislative change that followed. However, in at least 2 cases, Anderson and Belmarsh, the government was well aware of the human rights arguments against the relevant legislation long before the judicial decision was handed down. In all 3 cases (especially in relation to Belmarsh), there is strong evidence to support the proposition that the government did not want to amend the relevant legislation but was compelled to by the judicial decision. Furthermore, in at least 2 cases, Belmarsh and $F$ and Thompson, there is some evidence to suggest that the new public policy, forced into place by the judicial decision, may be less effective than the old. It seems strained, to say the least, to describe as 'dialogue' a process whereby one party knows the arguments against its position, does not accept them, receives a 'signal'

${ }^{173}$ Young (n 2) 10. 


\section{DIALOGUE AND DECLARATIONS OF INCOMPATIBILITY UNDER SECTION 4 OF THE HUMAN RIGHTS ACT 1998}

from another party that those arguments should be accepted, then complies with those arguments even though they disagree with them for perfectly valid reasons. ${ }^{174}$

Whether or not the process is described as 'dialogue', 'institutional interaction' or something else is probably irrelevant; what is important is to recognise that parliament does not, in reality, have much, if any, freedom to disagree with the conclusions of the courts on questions of rights when a declaration has been made. This has obvious implications for the traditional notion of parliamentary sovereignty in the United Kingdom. As predicted by Mark Tushnet, the HRA may very well have escalated into what is effectively strong-form judicial review. ${ }^{175}$

As cases such as $R(H) v$ London North and East Region Mental Health Review Tribunal indicate, it is possible that the making of a declaration might lead to a constructive modification of public policy (from a rights perspective). However, as Belmarsh and $F$ and Thompson suggest, it is also possible that declarations might lead to less effective policy. Further research in this respect is clearly required, especially in circumstances where parliament appears to have at least some capability of dealing with rights issues in the absence of 'signals' in the form of s 4 declarations. If the policy benefits of 'dialogue' are negligible then the wisdom of revising the longestablished model of responsible government in the United Kingdom might be called into question.

\footnotetext{
${ }^{174}$ See Sales and Ekins (n 15) 230 but cf Alison Young, 'Is dialogue working under the Human Rights Act 1998?' [2011] PL 773.

${ }^{175}$ Mark Tushnet, 'New Forms of Judicial Review and the Persistence of Rights and Democracy-Based Worries' (2003) 38 Wake Forest L Rev 813, 836.
} 